\title{
Utjecaj modelnih otopina na poli(3-hidroksibutirat)/montmorilonit kompozite
}

\author{
S. Perinović Jozić, A. Mihovilovići B. Andričić
}

\begin{abstract}
Sažetak
Cilj ovog rada bio je pripremiti poli(3-hidroksibutirat)/montmorilonit (PHB/MMT) kompozite na laboratorijskoj preši uz zagrijavanje te odrediti utjecaj različitih modelnih otopina na kompozite i migraciju punila. Analiza modelnih otopina nakon ispitivanja migracije provedena je pomoću UV/Vis spektroskopije. Zbog utvrđene hidrolize PHB-a pod utjecajem modelnih otopina nemoguće je odrediti migraciju MMT-a iz kompozita PHB/MMT. Diferencijalna pretražna kalorimetrija (DSC) potvrdila je razgradnju PHB-a. Provedenim istraživanjem ukazalo se na potencijal uporabe UV/Vis spektroskopije kod ispitivanja utjecaja modelnih otopina na polimerne kompozite.
\end{abstract}

Ključne riječi

Poli(3-hidroksibutirat), montmorilonit, modelne otopine, migracija, UV-Vis spektroskopija, toplinska svojstva

\section{Uvod}

Polimerni materijali imaju široku primjenu u svim područjima ljudske djelatnosti, pa se tako u velikoj mjeri upotrebljavaju i u prehrambenoj industriji kao ambalažni materijali. Specifična svojstva polimernih materijala omogućila su razvoj novih tehnika pakiranja i nove ambalažne oblike, čime se proširio spektar roba za pakiranje. ${ }^{1}$ Primarni cilj ambalaže je održavanje hrane što duže svježom te sprječavanje njezina kvarenja od strane vanjskih faktora. Dakle, zaštitna funkcija ambalaže, bilo da se radi o polimernim materijalima ili nekim drugim, je zaštita od mehaničkih naprezanja, klimatskih utjecaja, elektromagnetskog zračenja, topline, mikroorganizama i raznih štetočina. ${ }^{1}$ Najvažniji polimeri koji se upotrebljavaju za izradu ambalaže pripadaju skupini plastomera a radi se o polietilenu, polipropilenu, polistirenu, poli(vinil-kloridu), poli(etilen-tereftalatu), poliamidima itd. ${ }^{2}$ Porastom primjene polimernih materijala porasle su i količine polimernog otpada i sve je više izražen problem njegova zbrinjavanja. S obzirom na to da su širokoprimjenjivi sintetski polimeri otporni na kemijsku i biološku razgradnju, jedan od načina djelomičnog rješavanja problema je uporaba polimera koji su biorazgradljivi i čiji produkti razgradnje nisu štetni za okoliš. Jedan od najvažnijih biorazgradljivih biopolimera je poli(3-hidroksibutirat) (PHB), potpuno biorazgradljiv alifatski poliester koji je iz skupine poli(hidroksialkanoata) i jedini se iz te skupine biopolimera industrijski proizvodi u većim količinama. ${ }^{3}$

Polimeri često ne mogu ispuniti zahtjeve koji se postavljaju pred njih kod pojedinih uporaba, pa im se dodaju sintetski ili prirodni anorganski materijali s ciljem poboljšavanja svojstva ili samo smanjivanja troškova proizvodnje. Nanokompoziti su relativno noviji materijali u kojima komponente nanometarskih dimenzija pridonose novim svojstvi-

*Autor za dopisivanje: doc. dr. sc. Sanja Perinović Jozić

e-pošta: sanja@ktf-split.hr

Rad je prezentiran na VII. hrvatskom simpoziju o kemiji i tehnologiji makromolekula 2019. ma materijala koja ne posjeduju ostali kompoziti ili čiste komponente. Najčešće uporabljena nanopunila su pločasta punila (npr. slojeviti silikati), nanovlakna i nanocjevčice te istoosna punila. ${ }^{4}$ Filosilikati (često nazvani i gline) najvažnija su skupina slojevitih silikata. ${ }^{3}$ Velika prednost im je što su uglavnom prirodnog podrijetla, a montmorilonit (MMT) je njihov najpoznatiji član koji se može smatrati nanopunilom samo ako je u kompozitu došlo do interkaliranja ili eksfolijacije nanopunila u polimernoj matrici. Svoje mjesto u prehrambenoj industriji, tj. u ambalažnim materijalima pronašli su zbog dobrih barijernih svojstava, a potencijal za uporabu vidi im se u aktivnoj i inteligentnoj ambalaži za hranu. ${ }^{5}$

Migracija nanopunila još uvijek nije dobro istražena a postaje gorući problem kako kod ambalažnih materijala tako i kod ostalih područja primjene polimernih materijala. Sve veća primjena nanopunila u ambalaži prehrambenih proizvoda iziskuje istraživanje njihova utjecaja na kvalitetu hrane, te je nužno odrediti zakonsku regulativu koja će definirati njihove dopuštene koncentracije u hrani. Utjecaj naopunila na kvalitetu hrane ne može se zanemariti jer može utjecati na ljudsko zdravlje. Ispitivanje migracije pojedinih tvari, tj. specifična migracija iz polimerne ambalaže najčešće se provodi pomoću kromatografskih tehnika vezanih na neku spektroskopsku tehniku. Različite regulativne institucije točno su odredile pojedine analitičke tehnike za neke, ali ne i sve migrante iz polimerne ambalaže, čime se ostavio prostor za proučavanje primjene novih, tj. drugih analitičkih tehnika. U slučaju iznimno složenog medija kao što je hrana istraživači posežu i za mikroskopijom (pretražni elektronski mikroskop, transmisijjki elektronski mikroskop, mikroskop atomskih sila itd.), spektroskopijom i ostalim tehnikama kako bi se povećale mogućnosti određivanja nanopunila, tj. nanočestica. ${ }^{6}$

Cilj ovog rada bio je pripremiti kompozite PHB/MMT te pomoću UV/Vis spektroskopije i diferencijalne pretražne kalorimetrije (DSC) odrediti utjecaj modelnih otopina na istraživane kompozite i migraciju punila. Kao modelne oto- 
pine upotrijebljene su destilirana voda (za namirnice čija je $\mathrm{pH}$ vrijednost > 4,5), 3 \%-tna otopina octene kiseline (za namirnice čija je $\mathrm{pH}$ vrijednost $<4,5$ ) i $15 \%$-tna otopina etanola (za namirnice koje sadržavaju alkohol). Primjena UV/Vis spektroskopije kao tehnike za određivanje migracije punila iz polimerne ambalaže je neistražena, tj. nema sličnih istraživanja, zbog čega se otvara čitav spektar polimernih kompozita i uvjeta za buduća istraživanja.

\section{Eksperimentalni dio}

\subsection{Materijali}

Za pripravu kompozita PHB/MMT upotrijebljen je praškasti poli(3-hidrokisibutirat), Biomer, Njemačka $\widehat{M_{v}}=385000 \mathrm{~g} \mathrm{~mol}^{-1}$ (određen viskozimetrijski primjenom jednažbe $\left.[\eta]=1,18 \cdot 10^{-4} \bar{M}_{v}{ }^{0}\right)^{3}$ te prirodni montmorilonit $\left(\mathrm{Na}^{+}-\mathrm{MMT}\right.$, tj. MMT), Southern Clay Products, Inc., SAD. Prije priprave kompozita praškaste mješavine PHB-a i MMT-a homogenizirane su miješanjem 5 min u ahatnom tarioniku. Priprava kompozita PHB/MMT provedena je na laboratorijskoj preši uz zagrijavanje (Specac, Engleska). Praškaste mješavine PHB/MMT rastaljene su u kalupima preše obloženim folijom poli(etilen-tereftalata) (PET) pri $190{ }^{\circ} \mathrm{C}$ uz zadržavanje oko $3 \mathrm{~min}$. Potpuno rastaljeni kompoziti zatim su isprešani masom od $5 \mathrm{t}$ u trajanju oko 2 min. Nakon uklanjanja kalupa iz preše dobiveni uzorci podvrgnuti su hlađenju u vodi sobne temperature oko 1 min. Izrađeno je po deset uzoraka istog sastava dimenzija $30 \mathrm{~mm} \times 10 \mathrm{~mm} \times 1 \mathrm{~mm}$, tablica 1 .

Tablica 1 - Sastav uzoraka kompozita PHB/MMT

Table 1 - Composition of PHB/MMT composites

\begin{tabular}{l|c|c}
\hline \multirow{2}{*}{$\begin{array}{l}\text { Uzorak } \\
\text { Sample }\end{array}$} & \multicolumn{2}{|c}{$\begin{array}{c}\text { Sastav uzorka } \\
\text { Sample composition }\end{array}$} \\
\hline 100PHB/0MMT & PHB/mas\% & MMT /mas\% \\
\hline $99 \mathrm{PHB} / 1 \mathrm{MMT}$ & 100 & 0 \\
\hline $95 \mathrm{PHB} / 5 \mathrm{MMT}$ & 99 & 1 \\
\hline $90 \mathrm{PHB} / 10 \mathrm{MMT}$ & 95 & 5 \\
\hline 50PHB/50MMT & 90 & 10 \\
\hline
\end{tabular}

\subsection{Ispitivanje migracije punila}

Kompoziti PHB/MMT bili su uronjeni u $6 \mathrm{ml}$ odgovarajuće modelne otopine (destilirana voda, $3 \%$-tna otopina octene kiseline i $15 \%$-tna otopina etanola) u epruveti, kako bi se ispitala migracija punila MMT. Za svaki uzorak kompozita PHB/MMT i svaku modelnu otopinu provedena su po tri ista ispitivanja (triplet). $U$ tablici 2 prikazani su nazivi uzoraka modelnih otopina u koje su bili uronjeni odgovarajući kompoziti PHB/MMT. Epruvete prekrivene PET folijom postave se na stalak koji se termostatira pri $40^{\circ} \mathrm{C}$ u vodenoj kupelji deset dana (termostat Huber CC3, Njemačka).
Tablica 2 - Oznake modelnih otopina za ispitivanje migracije Table 2 - Mark of food simulants for migration testing

\begin{tabular}{|c|c|c|}
\hline $\begin{array}{l}\text { Uzorak kompozita } \\
\text { Sample of composite }\end{array}$ & \multicolumn{2}{|c|}{$\begin{array}{l}\text { Oznaka modelne otopine } \\
\text { Mark of the food simulants }\end{array}$} \\
\hline \multirow{3}{*}{ 100PHB/OMMT } & destilirana voda & D1, D2, D3 \\
\hline & $\begin{array}{l}3 \% \text {-tna otopina } \\
\text { octene kiseline }\end{array}$ & O4, O5, O6 \\
\hline & $\begin{array}{l}15 \% \text {-tna otopina } \\
\text { etanola }\end{array}$ & E7, E8, E9 \\
\hline \multirow{3}{*}{ 99PHB/1MMT } & destilirana voda & D10, D11, D12 \\
\hline & $\begin{array}{l}3 \% \text {-tna otopina } \\
\text { octene kiseline }\end{array}$ & O13, O14, O15 \\
\hline & $\begin{array}{l}15 \% \text {-tna otopina } \\
\text { etanola }\end{array}$ & E16, E17, E18 \\
\hline \multirow{3}{*}{ 95PHB/5MMT } & destilirana voda & D19, D20, D21 \\
\hline & $\begin{array}{l}3 \% \text {-tna otopina } \\
\text { octene kiseline }\end{array}$ & $\mathrm{O} 22, \mathrm{O} 23, \mathrm{O} 24$ \\
\hline & $\begin{array}{l}15 \% \text {-tna otopina } \\
\text { etanola }\end{array}$ & E25, E26, E27 \\
\hline \multirow{3}{*}{ 90PHB/10MMT } & destilirana voda & D28, D29, D30 \\
\hline & $\begin{array}{l}3 \% \text {-tna otopina } \\
\text { octene kiseline }\end{array}$ & O31, O32, O33 \\
\hline & $\begin{array}{l}15 \% \text {-tna otopina } \\
\text { etanola }\end{array}$ & E34, E35, E36 \\
\hline \multirow{3}{*}{ 50PHB/50MMT } & destilirana voda & D37, D38, D39 \\
\hline & $\begin{array}{l}3 \% \text {-tna otopina } \\
\text { octene kiseline }\end{array}$ & O40, O41, O42 \\
\hline & $\begin{array}{l}15 \% \text {-tna otopina } \\
\text { etanola }\end{array}$ & E43, E44, E45 \\
\hline
\end{tabular}

\subsection{UV/Vis spektroskopija}

Određivanje prisutnosti MMT-a u modelnim otopinama nakon provedenog ispitivanja migracije (tablica 2) provedeno je pomoću UV/Vis spektrometra (Secomam XTD 5, Francuska) u mjernom području 190 - 400 nm, a na temelju izrađenih baždarnih dijagrama (referentne suspenzije $0,005,0,010,0,015$ i 0,020\% (w/v) MMT-a u modelnim otopinama imaju oznake 0,005-0,020MMTD, 0,0050,020MMTO i 0,005-0,020MMTE) odredit će se njegova nepoznata koncentracija. Valna duljina $(\lambda)$ koja služi za određivanje prisutnosti MMT-a u modelnim otopinama je oko $242 \mathrm{~nm}{ }^{7}$ Nakon određene apsorbancije (A) pomoću jedn. 1 nacrtaju se baždarni pravci uz uvjet da su $\varepsilon$ (molarni apsorpcijski koeficijent) i $d$ (debljina kivete, $1 \mathrm{~cm}$ ) konstantni:

$$
A=\varepsilon \cdot c \cdot d \rightarrow A=(c)
$$

Analiza dobivenih podataka modelnih otopina nakon provedenog ispitivanja migracije ukazala je na potrebu priprave suspenzija PHB-a u prethodno odabranim modalnim otopinama (referentne suspenzije $0,1 \%(w / v)$ s oznakama PHB-D, PHB-O i PHB-E) zbog identifikacije prisutnosti PHB-a. 


\subsection{Diferencijalna pretražna kalorimetrija}

Za analizu toplinskih svojstava pripravljenih kompozita prije i nakon ispitivanja migracije upotrijebljen je diferencijalni pretražni kalorimetar (DSC 823e, Mettler Toledo, Švicarska) opremljen sustavom za hlađenje ispod sobne temperature (engl. Intracooler). Instrument je kalibriran indijem $\left(T_{\mathrm{m}}=156,6{ }^{\circ} \mathrm{C}, \Delta H_{\mathrm{m}}=28,45 \mathrm{~J} \mathrm{~g}^{-1}\right)$. Prije početka rada sustav je stabiliziran od 0,5 do $1 \mathrm{~h}$. Mjerenja su provedena u zatvorenim aluminijskim posudicama probušenih poklopaca u atmosferi dušika $\left(30 \mathrm{~cm}^{3} \mathrm{~min}^{-1}\right)$. Masa ispitaka pripravljenih kompozita bila je oko $10 \mathrm{mg}$. Ispitci sobne temperature najprije su ohlađeni na $-50{ }^{\circ} \mathrm{C}$ brzinom $20{ }^{\circ} \mathrm{C} \min ^{-1}$ te od $-50{ }^{\circ} \mathrm{C}$ zagrijani do $200{ }^{\circ} \mathrm{C}$ brzinom $20^{\circ} \mathrm{C} \mathrm{min}^{-1}$ (prvo zagrijavanje), zatim su ohlađeni na $-50{ }^{\circ} \mathrm{C}$ brzinom $20^{\circ} \mathrm{C} \mathrm{min}^{-1}$ (hlađenje) nakon čega su ponovo zagrijani na $200{ }^{\circ} \mathrm{C}$ brzinom $20{ }^{\circ} \mathrm{C} \mathrm{min}{ }^{-1}$ (drugo zagrijavanje). Temperatura hladne kristalizacije $\left(T_{\text {cc }}\right)$, temperatura kristalizacije iz taline $\left(T_{\mathrm{mc}}\right)$ i temperatura taljenja $\left(T_{\mathrm{m}}\right)$ određene su kao temperature u vršku egzoterme ili endoterme prijelaza (hladna kristalizacija, kristalizacija iz taline, taljenje). Iz navedenih prijelaza određene su i pripadajuće topline (toplina hladne kristalizacije $\left(\Delta H_{c c}\right)$, toplina kristalizacije iz taline $\left(\Delta H_{\mathrm{mc}}\right)$ i toplina taljenja $\left.\left(\Delta H_{\mathrm{m}}\right)\right)$. Temperatura staklastog prijelaza $\left(T_{\mathrm{g}}\right)$ određena je kao temperatura pri kojoj je promjena toplinskog kapaciteta $\left(\Delta c_{p}\right)$ jednaka polovini njegove maksimalne vrijednosti. Pomoću vrijednosti topline taljenja $\left(\Delta H_{\mathrm{m}}\right)$, sume toplina svih kristalizacija $\left(\Sigma \Delta H_{\mathrm{c}}\right)$ PHB-a u kompozitima i topline taljenja potpuno kristalnog PHB-a $\left(\Delta H_{100 \%}\right)$ moguće je izračunati stupanj kristalnosti $\left(X_{C}\right)$ primjenom jedn. (2):

$$
X_{\mathrm{C}} / \%=\frac{\left|\Delta H_{\mathrm{m}}\right|-\sum \Delta H_{\mathrm{C}}}{\Delta H_{100 \%} \cdot W_{\mathrm{PHB}}} \cdot 100
$$

gdje $\Delta H_{100 \%}$ iznosi $146 \mathrm{Jg}^{-1}$, a $w$ predstavlja maseni udio PHB-a u kompozitu. 3,8

Uzorci kompozita PHB/MMT nakon ispitivanja migracije dobili su oznake modelnih otopina u kojim su migracije povedene. Kao na primjer, 100PHB/0MMT-DX (destilirana voda), 100PHB/0MMT-OX (3 \%-tna otopina octene kiseline) i 100PHB/0MMT-EX (15 \%-tnoj otopini etanola). Oznaka X u nazivu uzorka predstavlja brojeve 1, 2 i 3 (triplet).

\section{Rezultati i rasprava}

\subsection{UV/Vis spektroskopija}

Na slikama 1a - 3a prikazani su UV/Vis spektri referentnih suspenzija MMT-a u destiliranoj vodi, 3 \%-tnoj otopini octene kiseline i $15 \%$-tnoj otopini etanola. Prikazani spektri služe za određivanje apsorbancije MMT-a u pojedinoj modelnoj otopini kako bi se mogli izraditi baždarni dijagrami (slike $1 b-3 b$ ) za određivanje količine migriranog MMT-a iz kompozita PHB/MMT.

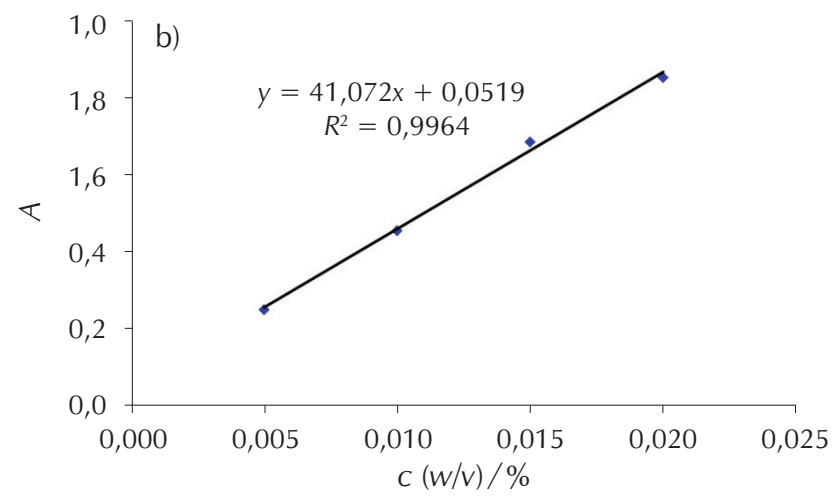

Slika 1 - a) UV/Vis spektri referentnih suspenzija MMT-a u destiliranoj vodi i b) pripadajući baždarni dijagram

Fig. 1 - a) UV/Vis spectra of the referent MMT suspensions in distilled water, and b) the associated calibration diagram
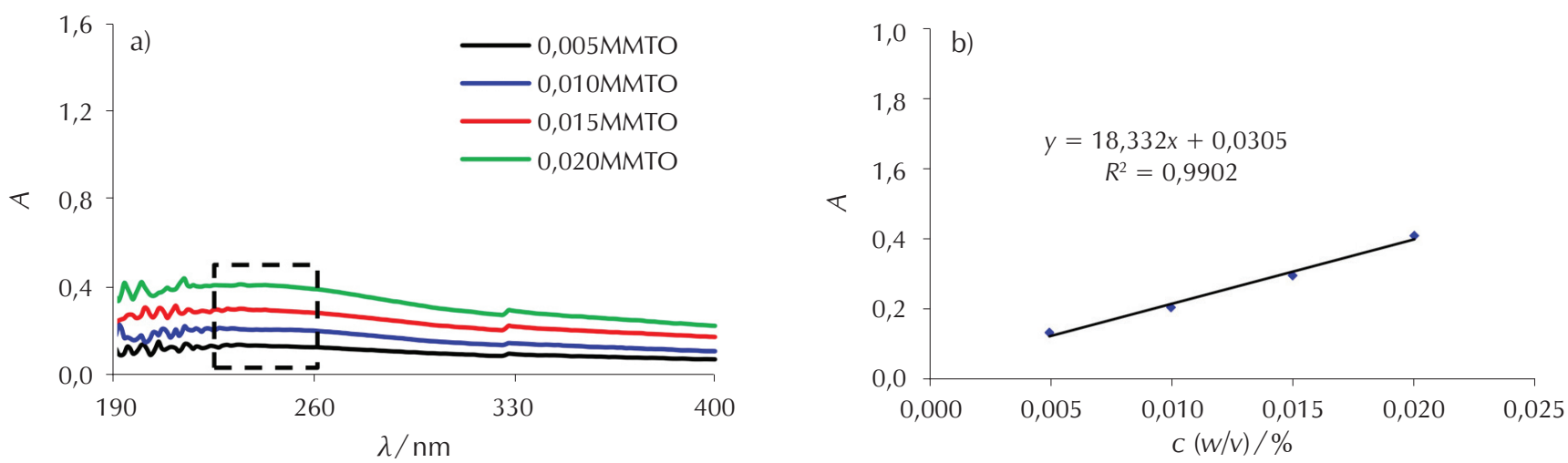

Slika 2 - a) UV/Vis spektri referentnih suspenzija MMT-a u 3 \%-tnoj otopini octene kiseline i b) pripadajući baždarni dijagram Fig. 2 - a) UV/Vis spectra of the referent MMT suspensions in $3 \%$ acetic acid solution, and b) the associated calibration diagram 

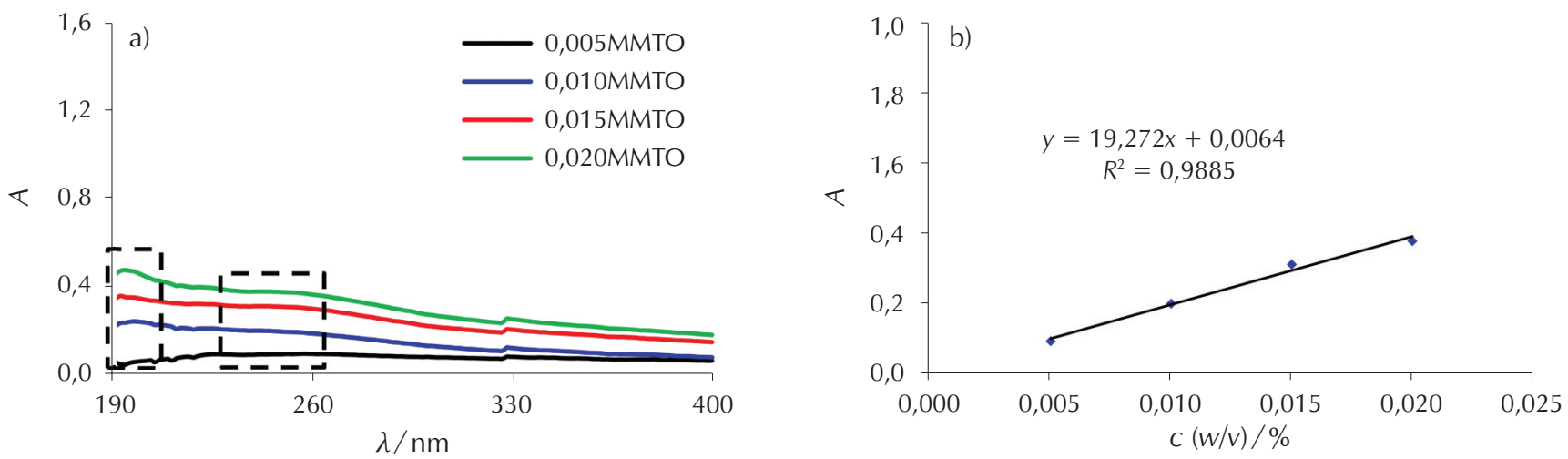

Slika 3 - a) UV/Vis spektri referentnih suspenzija MMT-a u 15 \%-tnoj otopini etanola i b) pripadajući baždarni dijagram

Fig. 3 - a) UV/Vis spectra of the referent MMT suspensions in $15 \%$ ethanol solution, and b) the associated calibration diagram

Intenzitet apsorpcije MMT-a najveći je u destiliranoj vodi , a najmanji u 3 \%-tnoj otopini octene kiseline. Razlog navedenom razjasnili su J. Alin $i$ sur. ${ }^{9}$ u svojem istraživanju primjene UV/Vis spektroskopije za određivanje aglomerata MMT-a u različitim suspenzijama, tj. određivanje njezina potencijala za mjerenje veličine MMT-a čestica nanometarskih i mikrometarskih dimenzija te određivanje granice detekcije MMT-a u odnosu na dimenziju čestica. Utvrdili su da su čestice MMT-a u vodi najmanje zbog hidrofilnosti, tj. afiniteta MMT-a prema vodi, kod $3 \%$-tne otopine octene kiseline dolazi do flokulacije uslijed snižavanja pH vrijednosti, pa su nakupine MMT-a veće, a u slučaju $100 \%$-tnog etanola nemaju UV/Vis podatke uslijed pojave precipitacije MMT-a. Ako se navedeno primijeni na rezultate dobivene ovim istraživanjem, uvjeti u $3 \%$-tnoj otopini octene kiseline i $15 \%$-tnoj otopini etanola su manje povoljni za određivanje prisutnosti MMT-a za razliku od destilirane vode, ali apsorpcijski maksimumi su ipak vidljivi. Nemodificirani montmoriloniti pokazuju intramolekulni prijenos naboja u području 191 - 195 nm i 241 - 243 nm, ali se u prvom valnom području zbog jake pozadine ne može dobro odrediti pozicija apsorpcijske vrpce. ${ }^{7,9}$ Zbog navedenog, valne duljine oko $242 \mathrm{~nm}$ upotrijebljene su za identifikaciju prisutnosti MMT-a u modelnim otopinama nakon migracije te izradu baždarnih dijagrama. Prema J. Alin i sur., ${ }^{9}$ sve dok u otopinama ili uzorcima različitih suspenzija MMT-a ima svega par ili čak nema dodatnih apsorpcijskih vrpci drugih prisutnih tvari, mogućih interferencija će biti malo. Sve referentne suspenzije pokazuju apsorpcijski maksimum oko $242 \mathrm{~nm}$ te povećanje apsorbancije s povećanjem koncentracije MMT-a u modelnim otopinama. Kod $3 \%$-tne otopine octene kiseline uočava se serija malih oštrih pikova u području od 190 do oko $230 \mathrm{~nm}$ koji se pojavljuju usred reakcija MMT-a s octenom kiselinom, pa se kod nje teže uočava ili uopće ne vidi prvo apsorpcijsko područje MMT-a. Baždarni dijagrami s danim jednadžbama pravaca i faktorima korelacije prikazani su na slikama $1 b-3 b$ a služe za određivanje nepoznate koncentracije migriranog MMT-a iz uzoraka kompozita u modelne otopine. Vrijednosti faktora korelacije su iznad 0,96, što ukazuje na primjenjivost UV/Vis spektroskopije i jedn. (1) (Lambert-Beerov zakon) u određivanju nepoznate koncentracije MMT-a u modelnim otopinama nakon migracije.
Slike 4, 6 i 7 prikazuju UV/Vis spektre nekih uzoraka modelnih otopina nakon provedenog ispitivanja migracije. UV/Vis spektri modelnih otopina prikazanih na slikama 4, 6 i 7 međusobno se razlikuju kao što je bilo vidljivo i kod spektara referentnih suspenzija MMT-a, ali ukazuju na nova apsorpcijska područja koja se djelomično ili potpuno preklapaju s apsorpcijskim područjima MMT-a. Kao što je već prethodno spomenuto, sve dok $u$ ispitivanim uzorcima ima malo ili nema uopće interferencija, određivanje prisutnosti MMT-a će biti jednostavno. Ako dolazi do preklapanja apsorpcijskih vrpci uslijed prisutnosti tvari koja apsorbira u blizini apsorpcijskih vrpci MMT-a bez provedenog procesa dekonvolucije krivulje UV/Vis spektra, nemoguće je potvrditi prisutnost apsorpcijskih vrpci, tj. pikova od interesa. B. T. Franzin $i$ sur. ${ }^{10}$ su dekonvoluciju UV/Vis spektara primijenili kako bi potvrdili prisutnost apsorpcijskih vrpci uslijed stvaranja kompleksa organofilnog montmorilonita s Fe(III) ionima. Proces dekonvolucije krivulje UV/Vis spektra nije jednostavan, pogotovo kad je riječ o nanočesticama, i zahtijeva složene programe. Pojava novih apsorpcijskih vrpci može biti odraz prisutnog PHB-a iz uzoraka kompozita uslijed razgradnje PHB-a, dezintegracije pločica pod djelovanjem modelnih otopina ili odraz interakcija komponenata kompozita s modelnim otopinama. Zbog pojave navedenih apsorpcijskih vrpci javila se potreba za pripravom suspenzija praha PHB u upotrijebljenim modelnim otopinama i analizom njihovih UVNVis spektara s ciljem što bolje interpretacije dobivenih rezultata, slika 5 . Pretraživanjem literature ${ }^{11-21}$ pronađena su istraživanja koja su se bavila pripravom PHB-a iz različitih kultura bakterija ili se ispitivala njegova razgradnja u različitim kiselim ili lužnatim otopinama, pri čemu su se u te svrhe koristili UV/Vis spektroskopijom. Određivanje prisutnosti PHB-a provodilo se preko njegovih glavnih produkata hidrolize, krotonske kiseline (CA) i 3-hidroksibutirinske kiseline (3HB). Razgradnja PHB-a najčešće se provodila pod djelovanjem koncentrirane sulfatne kiseline (izrazito kiseli medij), razrjeđivanjem tako dobivenih hidrolizata te analizom na UV/Vis spektrometru. ${ }^{12,14,15,17-19}$ Valne duljine koje su uzete kao mjerodavne za određivanje prisutnosti PHB-a, tj. CA su oko $235 \mathrm{~nm}$ a 3 HB oko 210 nm. ${ }^{11-21}$ Yu i sur. ${ }^{15}$ su u svojem istraživanju vrlo opširno istražili, opisali i usporedili abiotsku hidrolizu PHB-a u kiseloj i lužnatoj sredini ističući važnost uvjeta provedbe eksperimenta (koncentracija kise- 

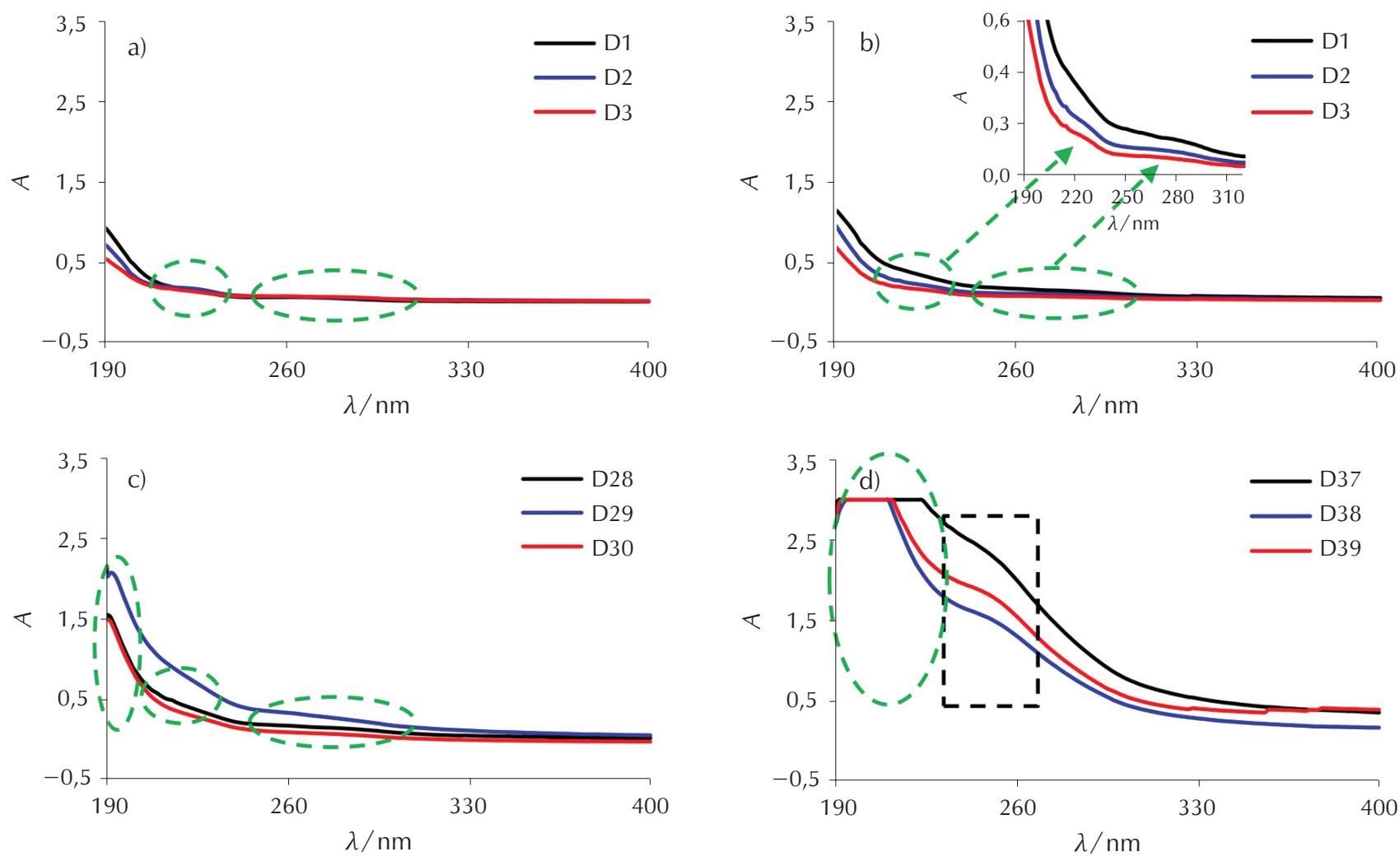

Slika 4 - UV/Vis spektri uzoraka destilirane vode nakon ispitivanja migracije provedenog na uzorcima sastava: a) 100PHB/0MMT-D, b) 99PHB/1MMT-D, c) 90PHB/10MMT-D i d) 50PHB/50MMT-D

Fig. 4 - UV/Vis spectra of the distillate water after migration tests on samples with different composition: a) 100PHB/0MMT-D, b) 99PHB/1MMT-D, c) 90PHB/10MMT-D i d) 50PHB/50MMT-D

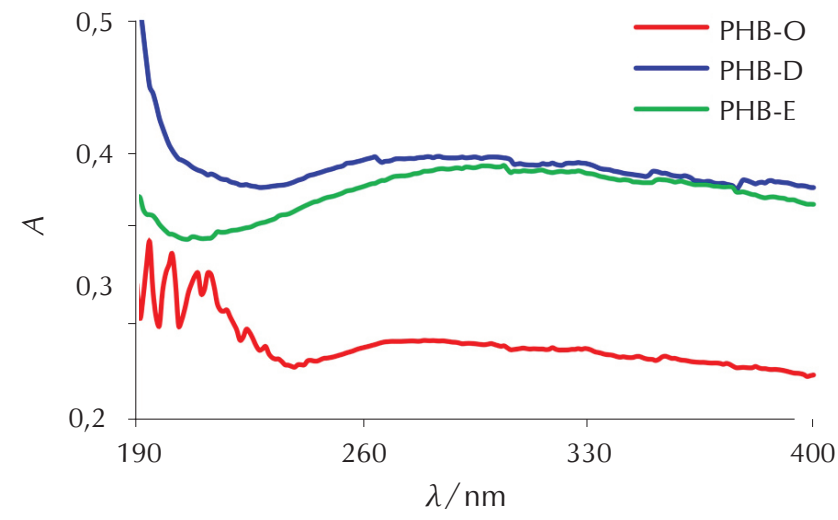

Slika 5 - UV/Vis spektri suspenzija PHB-a u destiliranoj vodi, $3 \%$-tnoj otopini octene kiseline i $15 \%$-tnoj otopini etanola

Fig. $5-$ UV/Vis spectra of the PHB suspensions in distilled water, $3 \%$ acetic acid solution and $15 \%$ ethanol solution

lih i lužnatih otopina, temperatura, vrijeme trajanja hidrolize itd.). Zaključili su kako se u lužnatom mediju stvaraju CA i 3 HB bez pojave međusobne konverzije uz predloženi novi mehanizam stvaranja CA, dok u kiselom mediju većinom dolazi do stvaranja CA a $3 \mathrm{HB}$ s vremenom podliježe dehidrataciji i prelazi u CA. Pregledom navedene, ali i ostale literature ${ }^{11-21}$ dolazi se do zaključka da kisela ili lužnata sredina s enzimima ili bez njih dovodi do razgrad- nje PHB-a najvećim dijelom na CA ili CA i $3 \mathrm{HB}$ uz ostale sporedne produkte razgradnje, što navodi na činjenicu da različiti $\mathrm{pH}$ mediji, tj. u slučaju ovog rada, različite modelne otopine i ostali uvjeti hidrolize (temperatura, vrijeme itd.) mogu dovesti do pojave navedenih hidrolizata PHB-a. Ovisno o tome što je nastalo u uzorku koji se ispituje, spomenute valne duljine mogu se pomicati prema manjim ili većim vrijednostima uslijed apsorpcija svih prisutnih tvari koje daju sumarni spektar. Ipak, zbog još uvijek nedovoljno razjašnjenje hidrolize $\mathrm{PHB}-\mathrm{a}$ uslijed uporabe različitih eksperimentalnih uvjeta od strane različitih istraživača, u ovom radu se provela analiza samo suspenzija praha $\mathrm{PHB}$ kako bi se vidio njegov utjecaj na UV/Nis spektre uzoraka. Daljnji cilj bio bi proširivanje ispitivanja s čitavim nizom mogućih produkata hidrolize PHB-a. Na UV/Vis spektrima suspenzija PHB-a u destiliranoj vodi, 3 \%-tnoj otopini octene kiseline i 15 \%-tnoj otopini etanola uočava se široka apsorpcijska vrpca PHB-a u područjima oko 230 - 310, 235 - 310 i $220-350 \mathrm{~nm}$ s apsorpcijskim maksimumima oko 275, 279 i 295 nm, slika 5. U slučaju suspenzije PHB-a u 3 \%-tnoj otopini octene kiseline dolazi do pojave niza oštrih vrpci u području 190 - 235 nm vjerojatno zbog reakcija octene kiseline s PHB-om.

Uzorci destilirane vode nakon provedenog ispitivanja migracije na pripravljenim kompozitima 100PHB/OMMT, tj. čistom PHB-u (slika 4a) imaju sličan oblik spektara kao i suspenzija PHB-a u destiliranoj vodi uz pojavu dva apsorpcijska područja. Prvo apsorpcijsko područje nalazi se 
između 215 i $240 \mathrm{~nm}$ s maksimumom oko $225 \mathrm{~nm}$, a drugo između 245 i $310 \mathrm{~nm}$. Kod dva od tri uzorka u drugom apsorpcijskom području uočava se njegovo blago razdvajanje na dva manja apsorpcijska područja s maksimumima oko 260 i 275 nm. Vrijednost 275 nm dobro se slaže s uočenom apsorpcijom kod suspenzije PHB-a u destiliranoj vodi. Maksimumi 225 i 260 nm ukazuju na pojavu drugih tvari u modelnoj otopini od kojih se maksimum oko $225 \mathrm{~nm}$ može pripisati, s obzirom na prethodno navedenu literaturu, ${ }^{11-21}$ apsorpciji od strane CA i 3HB nastalih uslijed djelovanja eksperimentalnih uvjeta na PHB s vjerojatno nastalom većom količinom CA. Treba napomenuti da se maksimum oko 260 nm uočava i kod drugih istraživanja, ${ }^{11-12}$ ali ga autori nisu interpretirali već su se isključivo bazirali na glavne produkte hidrolize PHB-a. Uzorci destilirane vode u kojima su se nalazili kompoziti s 1 - 10 mas\% MMT-a (slike 4b i 4c) također pokazuju navedena, ali intenzivnija apsorpcijska područja. Kod destilirane vode nakon ispitivanja migracije provedene na uzorcima kompozita s 10 mas\% MMT-a javlja se i izražena apsorpcijska vrpca s maksimumom oko $190 \mathrm{~nm}$ a mogla bi ukazivati na prisutnost MMT-a. Već je prethodno spomenut problem s navedenim apsorpcijskim područjem, a kako se kod čistog PHB-a također javlja naznaka apsorpcije u istom dijelu spektra, nepouzdano je tvrditi od koje tvari potječe signal. $\cup$ destiliranoj vodi nakon provedenog ispitivanja migracije na uzorcima kompozita 50PHB/50MMT (slika 4d) javlja se nepotpuna apsorpcijska vrpca između 190 i 235 nm, odnosno ne vidi se cijeli pik zbog velike koncentracije tva- ri koja apsorbira u tom području. Apsorbancija je daleko iznad granica detekcije uređaja. Uz spomenuto apsorpcijsko područje javlja se još i izražena apsorpcijska vrpca u području oko 235 - 310 nm s maksimumom oko 245 nm koja bi mogla ukazivati na prisutnost MMT-a, međutim kako su se uzorci kompozita s najvećim udjelom punila raspali tijekom ispitivanja, ne mogu se promatrati s aspekta migracije punila. Vjerojatno je došlo i do jake apsorpcije od strane CA i 3 HB te dobiveni spektar čini sumu apsorpcija prisutnih tvari u takvoj modelnoj otopini. Kod uzorka s velikim udjelom punila to je bio očekivan rezultat utjecaja modelne otopine, ali oni su i pripravljeni samo s ciljem pomaganja interpretaciji rezultata ostalih uzoraka. Povećanjem udjela MMT-a u kompozitima povećava se utjecaj destilirane vode tijekom ispitivanja uslijed lakšeg prodiranja modelne otopine u uzorke kompozita. Razlog tome je hidrofilnost MMT-a, čime se vjerojatno povećava površina PHB-a za hidrolizu.

Uzorci $3 \%$-tne otopine octene kiseline nakon provedenog ispitivanja migracije na uzorcima kompozita koji sadrže 0 - 10 mas\% MMT-a pokazuju već spomenuti niz malih oštrih vrpci u području 190 - 215 nm, apsorpcijsku vrpcu u području 220 - $255 \mathrm{~nm} \mathrm{~s}$ maksimumom pri $233 \mathrm{~nm}$ i manju slabu široku vrpcu u području 260 - 320 nm (slike $6 \mathrm{a}-6 \mathrm{c}$ ). Vrijednost $233 \mathrm{~nm}$ jasno ukazuje na prisutnost isključivo CA u uzorcima prema prethodno spomenutoj literaturi ${ }^{12,14,15,17-19}$ a nastaje hidrolizom PHB-a u kiselom mediju. Usporedbom tih rezultata s rezultatima dobive-
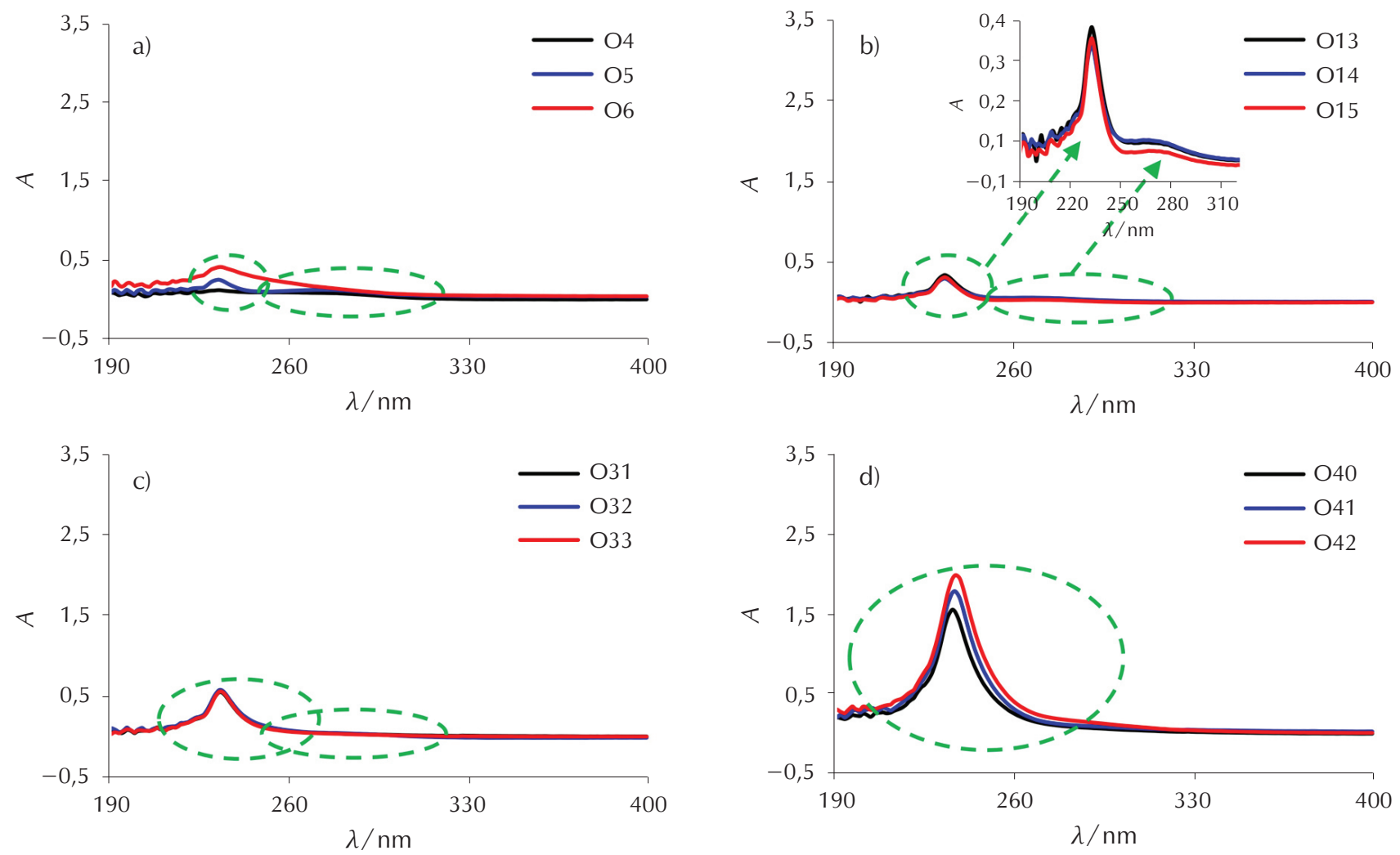

Slika 6 - UV/Vis spektri uzoraka 3 \%-tne otopine octene kiseline nakon ispitivanja migracije provedenog na uzorcima kompozita: a) 100PHB/0MMT-O, b) 99PHB/1MMT-O, c) 90PHB/10MMT-O i d) 50PHB/50MMT-O

Fig. 6 - UV/Vis spectra of the $3 \%$ acetic acid solution after migration test on the samples of the composites: a) 100PHB/0MMT-O, b) 99PHB/1MMT-O, c) 90PHB/10MMT-O i d) 50PHB/50MMT-O 

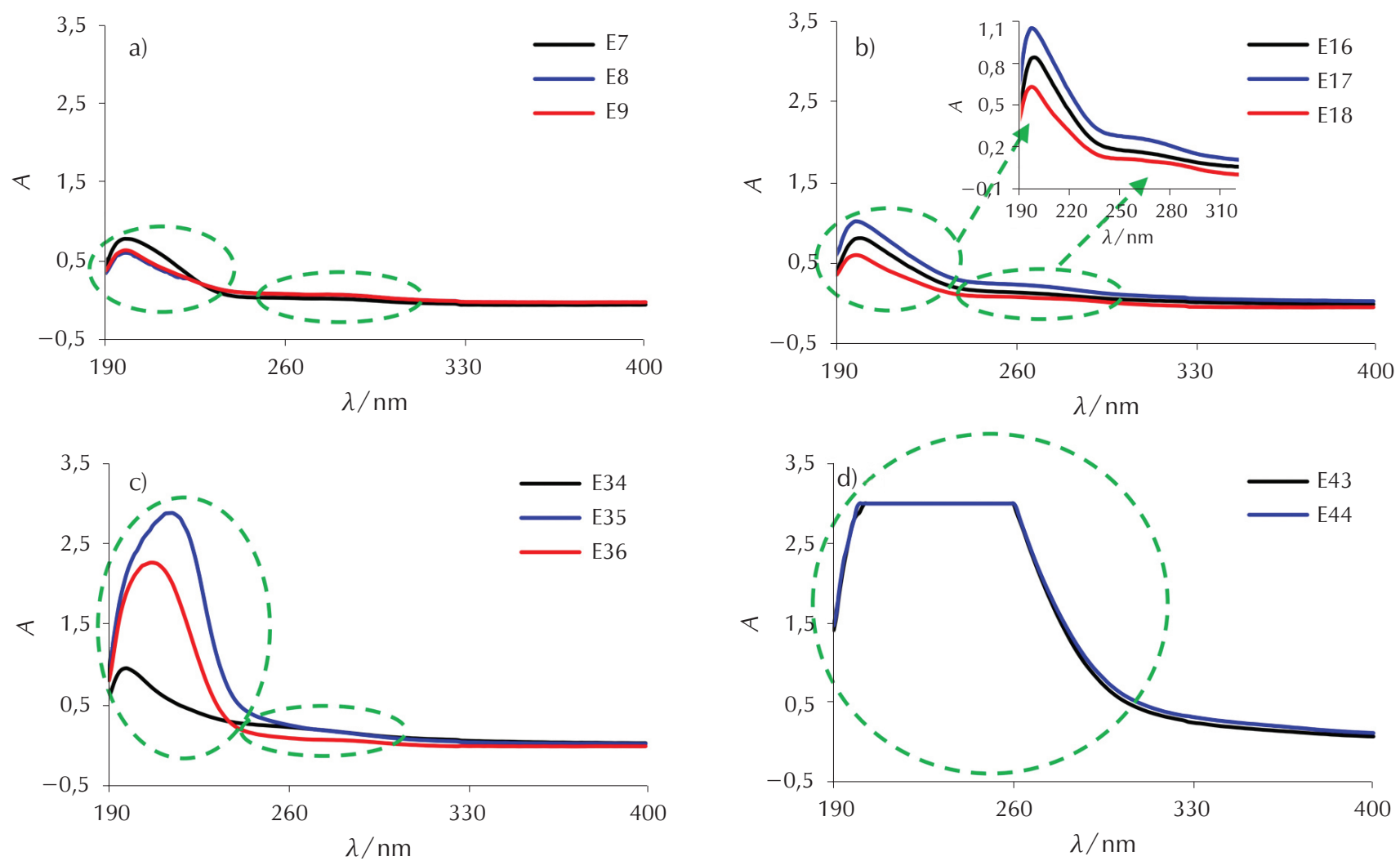

Slika 7 - UV/Vis spektri uzoraka $15 \%$-tne otopine etanola nakon ispitivanja migracije provedenog na uzorcima kompozita: a) $100 \mathrm{PHB} / 0 \mathrm{MMT}-\mathrm{E}$, b) $99 \mathrm{PHB} / 1 \mathrm{MMT}-\mathrm{E}$, c) $90 \mathrm{PHB} / 10 \mathrm{MMT}-\mathrm{E}$ i d) $50 \mathrm{PHB} / 50 \mathrm{MMT}-\mathrm{E}$

Fig. 7 - UV/Vis spectra of the $15 \%$ ethanol solution after migration tests on samples of the composites: a) 100PHB/0MMT-E, b) 99PHB/1MMT-E, c) 90PHB/10MMT-E i d) 50PHB/50MMT-E

nim u destiliranoj vodi potvrdio se utjecaj različitih uvjeta na hidrolizu PHB-a. Kod nekih uzoraka 3 \%-tne otopine octene kiseline u drugom apsorpcijskom području uočava se njegovo blago razdvajanje na dva manja apsorpcijska područja s maksimumima oko 260 i $275 \mathrm{~nm}$, ili se samo uočava jedno pri oko 260 ili 275 nm ovisno o količini prisutne tvari u modelnoj otopini. Kako je već prethodno navedeno kod uzoraka destilirane vode, vrijednost $260 \mathrm{~nm}$ ukazuje na prisutnost još nekih tvari koje su nastale tijekom hidrolize PHB-a. Vrijednost $275 \mathrm{~nm}$ također se dobro slaže s uočenim apsorpcijskim maksimumom pri $279 \mathrm{~nm}$ kod suspenzije PHB-a u 3 \%-tnoj otopini octene kiseline dokazujući prisutnost i nehidroliziranog PHB-a. U uzorcima $3 \%$-tne otopine octene kiseline nakon provedenog ispitivanja migracije na uzorcima kompozita 50PHB/50MMT (slika 6d) javlja se samo jaka, oštra apsorpcijska vrpca u području 210 - $310 \mathrm{~nm}$ s apsorpcijskim maksimumom pri $237 \mathrm{~nm}$ koja prema literaturi ${ }^{12,14,15,17-19}$ pripada CA. Uzorci kompozita s najvećim udjelom punila također su se raspali tijekom ispitivanja migracije, pa spektar prikazuje ukupnu apsorpciju od strane svih prisutnih tvari u takvoj modelnoj otopini s najjačom apsorpcijom od strane CA. Povećanjem udjela MMT-a u kompozitima povećava se utjecaj 3 \%-tne otopine octene kiseline. U slučaju uzoraka 3 \%-tne otopine octene kiseline nakon provedenog ispitivanja migracije ne može se potvrditi prisutnost MMT-a.

UV/Vis spektri uzoraka $15 \%$-tne otopine etanola nakon provedenog ispitivanja migracije na uzorcima kompozi- ta koji sadrže 0 - 5 mas\% MMT-a (slike 7a i 7b) imaju jače izraženu apsorpcijski vrpcu u području 190 - 245 nm s maksimumom pri oko $200 \mathrm{~nm}$ i manju u području 250 - 310 nm. Uočen maksimum oko 200 nm više ukazuje na prisutnost veće količine 3HB-a u odnosu na CA prema prethodno spomenutoj literaturi. ${ }^{13,15,16,20,21}$ Kod nekih uzoraka 15 \%-tne otopine etanola u drugom apsorpcijskom području uočava se njegovo blago razdvajanje na dva manja apsorpcijska područja s maksimumima oko 260 i 280 nm, ili se samo uočava jedno pri oko 260 ili 280 nm. Uočeno je već prethodno objašnjeno kod uzoraka destilirane vode i $3 \%$-tne otopine octene kiseline. Uzorci $15 \%$-tne otopine etanola u kojima su se nalazili kompoziti s 10 mas\% MMT-a (slika 7c) također pokazuju navedena, ali intenzivnija apsorpcijska područja. Kod apsorpcijskog područja 190 - $245 \mathrm{~nm}$ maksimumi su ipak više pomaknuti prema $215 \mathrm{~nm}$. Ukazujući prema literaturi13,15,16,20,21 i dalje na prisutnost vjerojatno veće količine $3 \mathrm{HB}-\mathrm{a}$ u odnosu na CA. Kod uzoraka $15 \%$-tne otopine etanola nakon provedenog ispitivanja migracije na uzorcima kompozita 50PHB/50MMT uočava se jedna jaka i široka nepotpuna apsorpcijska vrpca u području 190 - 340 nm. Uzorci kompozita s najvećim udjelom punila također su se raspali tijekom ispitivanja migracije pa i kod njih spektar prikazuje ukupnu apsorpciju od strane svih prisutnih tvari u takvoj modelnoj otopini. Treba naglasiti da se intenzitet uočenih apsorpcijskih vrpci i kod $15 \%$-tne otopine etanola povećava s povećanjem udjela MMT-a u kompozitima PHB/MMT. U slučaju uzoraka $15 \%$-tne otopine etanola nakon prove- 
denog ispitivanja migracije ne može se potvrditi prisutnost MMT-a, ali su rezultati i te modelne otopine potvrdili utjecaj različitih uvjeta na hidrolizu PHB-a.

Uzimajući u obzir složenost priprave i analize uzoraka, razlike u intenzitetima apsorpcije, ali ne u valnim područjima, koje se javljaju između pojedinih tripleta su zanemarive i ukazuju na dobar protokol priprave uzoraka. Interpretacija UV/Vis spektara kod istraživanih kompozita i modelnih otopina pokazala se složena, ali je ukazala na potencijal uporabe UV/Vis spektroskopije kod ispitivanja utjecaja modelnih otopina na polimerne kompozite. $U$ budućim istraživanjima primijenit će se i druge instrumentalne tehnike da bi se u potpunosti razjasnio utjecaj modelnih otopina na kompozite PHB/MMT te utvrdilo migriranje MMT-a koje zbog hidrolize PHB-a s UV/Vis spektrometrom nije bilo moguće. Istraživanje će se također proširiti i na druge polimerne kompozite, tj. druge vrsta punila u istoj ili nekoj drugoj polimernoj matrici i na druge modelne otopine.

\subsection{Diferencijalna pretražna kalorimetrija}

Primjenom diferencijalne pretražne kalorimetrije istraživan je utjecaj modelnih otopina na toplinska svojstva i kristalnost kompozita PHB/MMT. Pod utjecajem modelnih otopina se misli o migraciji punila iz kompozita i/ili interakciji modelnih otopina s komponentama kompozita PHB/MMT. Na slikama 8 i 9 prikazane su DSC krivulje prvog zagrijavanja, hlađenja i drugog zagrijavanja kompozita prije i nakon ispitivanja migracije u odgovarajućoj modelnoj otopini. Treba napomenuti kako su se kompoziti 50PHB/50MMT stajanjem u modelnim otopinama raspali te se nisu mogli analizirati na DSC-u. To je i bilo očekivano s obzirom na velik udio punila u kompozitu. Krivulje prvog zagrijavanja odraz su utjecaja toplinske prošlosti kompozita i utjecaja modelnih otopina na toplinska svojstva i kristalnost kompozita PHB, a krivulje drugog zagrijavanja predstavljaju samo utjecaj modelnih otopina. Na prikazanim DSC krivuljama prvog i drugog zagrijavanja uočava se pojava više
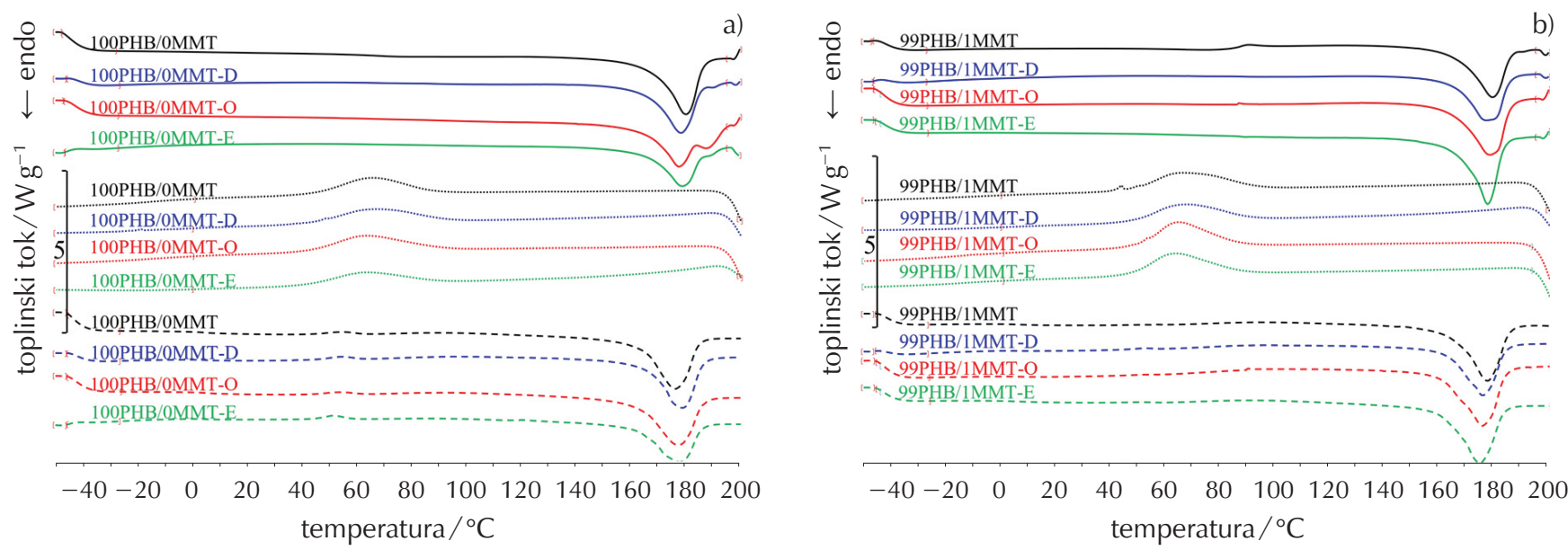

Slika 8 - DSC krivulje prvog zagrijavanja (-), hlađenja (․) i drugog zagrijavanja (--) kompozita prije i nakon ispitivanja migracije: a) $100 \mathrm{PHB} / 0 \mathrm{MMT}$ i b) $99 \mathrm{PHB} / 1 \mathrm{MMT}$

Fig. 8 - DSC curves of the first heating $(-)$, cooling ( $\cdots)$, and second heating (--) of the composites before and after migration testing: a) $100 \mathrm{PHB} / 0 \mathrm{MMT}$, and b) $99 \mathrm{PHB} / 1 \mathrm{MMT}$
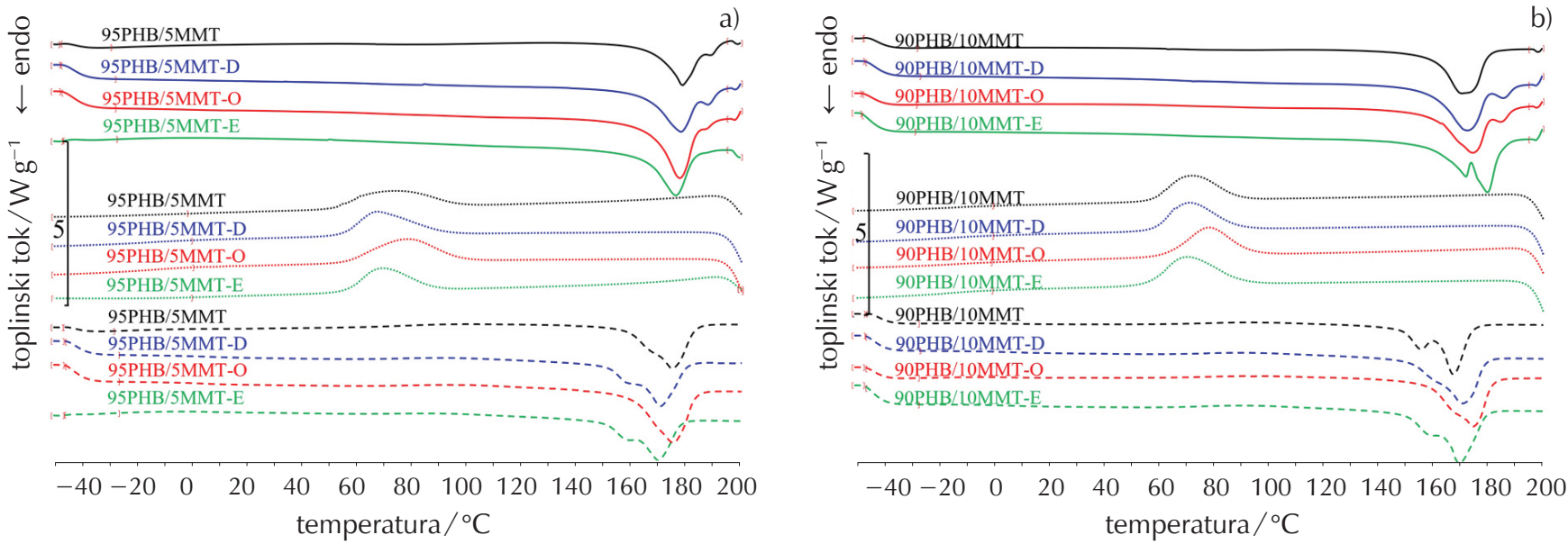

Slika 9 - DSC krivulje prvog zagrijavanja (-), hlađenja (․) i drugog zagrijavanja (--) kompozita prije i nakon ispitivanja migracije: a) $95 \mathrm{PHB} / 5 \mathrm{MMT}$ i b) $90 \mathrm{PHB} / 10 \mathrm{MMT}$

Fig. 9 - DSC curves of the first heating (-), cooling ( $\cdots)$, and second heating (--) of the composites before and after migration testing: a) $95 \mathrm{PHB} / 5 \mathrm{MMT}$, and b) $90 \mathrm{PHB} / 10 \mathrm{MMT}$ 
endotermnih pikova koji su manje ili više izraženi (dva manja i jedan veći pik), tj. dolazi do njihovih preklapanja. Značajke DSC krivulja prvog zagrijavanja i hlađenja ispitaka kompozita PHB/MMT prije i nakon ispitivanja migracije dane su u tablici 3, a za drugo zagrijavanje u tablici 4 .
Hladna kristalizacija se nakon prvog zagrijavanja javlja samo kod uzoraka kompozita 99PHB/1MMT, a nakon drugog zagrijavanja kod uzoraka 100PHB/OMMT prije i nakon ispitivanja migracije u svim modelnim otopinama te uzorku 99PHB/1MMT-D. Radi se o slabo izraženom to-

Tablica 3 - Značajke DSC krivulja prvog zagrijavanja i hlađenja kompozita PHB/MMT prije i nakon ispitivanja migracije

Table 3 - DSC characteristics of the first heating and cooling curve of PHB/MMT composites before and after migration testing

\begin{tabular}{|c|c|c|c|c|c|c|c|c|c|}
\hline $\begin{array}{l}\text { Uzorak } \\
\text { Sample }\end{array}$ & $T_{\mathrm{pcc1}} /{ }^{\circ} \mathrm{C}$ & $\Delta H_{\mathrm{cc} 1} / \mathrm{Jg}^{-1}$ & $T_{1 \mathrm{pm} 1} /{ }^{\circ} \mathrm{C}$ & $\mathrm{T}_{2 \mathrm{pm} 1} /{ }^{\circ} \mathrm{C}$ & $T_{3 \mathrm{pm} 1} /{ }^{\circ} \mathrm{C}$ & $-\Delta H_{\mathrm{m} 1} / \mathrm{Jg}^{-1}$ & $X_{\mathrm{c} 1} / \%$ & $T_{\mathrm{pmc}} /{ }^{\circ} \mathrm{C}$ & $\Delta H_{\mathrm{mc}} / \mathrm{Jg}^{-1}$ \\
\hline 100PHB/0MMT & & & & 179 & & 74,8 & 51,2 & 65 & 42,6 \\
\hline 100PHB/OMMT-D & & & & 178 & 190 & 69,3 & 47,5 & 67 & 43,7 \\
\hline 100PHB/0MMT-O & & & & 177 & 187 & 71,8 & 49,2 & 64 & 42,9 \\
\hline 100PHB/OMMT-E & & & & 178 & 189 & 56,8 & 38,9 & 63 & 33,3 \\
\hline 99PHB/1MMT & 90 & 2,3 & & 178 & 191 & 59,5 & 39,6 & 66 & 48,0 \\
\hline 99PHB/1MMT-D & & & & 176 & & 63,7 & 44,1 & 67 & 41,8 \\
\hline 99PHB/1MMT-O & & & & 177 & & 77,3 & 53,5 & 65 & 52,2 \\
\hline 99PHB/1MMT-E & & & & 177 & & 74,2 & 51,3 & 64 & 48,2 \\
\hline $95 \mathrm{PHB} / 5 \mathrm{MMT}$ & & & & 178 & 189 & 61,5 & 44,3 & 74 & 46,5 \\
\hline 95PHB/5MMT-D & & & & 177 & 188 & 66,9 & 48,2 & 68 & 50,0 \\
\hline 95PHB/5MMT-O & & & & 177 & 187 & 75,8 & 54,7 & 79 & 55,3 \\
\hline 95PHB/5MMT-E & & & & 176 & 187 & 59,4 & 42,8 & 70 & 43,9 \\
\hline 90PHB/10MMT & & & & 170 & & 66,3 & 50,5 & 73 & 47,1 \\
\hline 90PHB/10MMT-D & & & & 171 & 185 & 72,9 & 55,5 & 72 & 51,7 \\
\hline 90PHB/10MMT-O & & & 163 & 174 & 184 & 74,9 & 57,0 & 79 & 50,2 \\
\hline 90PHB/10MMT-E & & & 171 & 179 & & 79,3 & 60,4 & 71 & 57,7 \\
\hline
\end{tabular}

Tablica 4 - Značajke DSC krivulja drugog zagrijavanja kompozita PHB/MMT prije i nakon ispitivanja migracije

Table 4 - DSC characteristics of the second heating curve of PHB/MMT composites before and after migration testing

\begin{tabular}{|c|c|c|c|c|c|c|c|c|c|}
\hline $\begin{array}{l}\text { Uzorak } \\
\text { Sample }\end{array}$ & $T_{\mathrm{mg}} /{ }^{\circ} \mathrm{C}$ & $\Delta c_{\mathrm{p}} / \mathrm{Jg}^{-1}{ }^{\circ} \mathrm{C}^{-1}$ & $T_{\mathrm{pcc} 2} /{ }^{\circ} \mathrm{C}$ & $\Delta H_{\mathrm{cc} 2} / \mathrm{Jg}^{-1}$ & $T_{1 \mathrm{pm} 2} /{ }^{\circ} \mathrm{C}$ & $T_{2 \mathrm{pm} 2} /{ }^{\circ} \mathrm{C}$ & $T_{3 \mathrm{pm} 2} /{ }^{\circ} \mathrm{C}$ & $-\Delta H_{\mathrm{m} 2} / \mathrm{Jg}^{-1}$ & $X_{\mathrm{c} 2} / \%$ \\
\hline 100PHB/0MMT & 4,8 & 0,202 & 54 & 2,4 & & 175 & & 79,2 & 52,6 \\
\hline 100PHB/OMMT-D & 5,4 & 0,088 & 54 & 2,4 & & 178 & & 76,0 & 50,4 \\
\hline 100PHB/0MMT-O & 5,0 & 0,169 & 53 & 2,1 & & 176 & & 80,8 & 53,9 \\
\hline 100PHB/OMMT-E & 5,0 & 0,050 & 51 & 2,9 & & 177 & & 59,8 & 39,0 \\
\hline 99PHB/1MMT & 6,4 & 0,104 & & & & 176 & & 78,0 & 54,0 \\
\hline 99PHB/1MMT-D & 5,7 & 0,075 & 52 & 0,6 & & 175 & & 66,8 & 45,8 \\
\hline 99PHB/1MMT-O & 5,5 & 0,192 & & & & 174 & & 81,2 & 56,2 \\
\hline 99PHB/1MMT-E & 4,8 & 0,124 & & & & 174 & & 76,8 & 53,1 \\
\hline 95PHB/5MMT & 7,3 & 0,042 & & & 167 & 174 & & 65,0 & 47,0 \\
\hline 95PHB/5MMT-D & 7,0 & 0,109 & & & 158 & 170 & & 69,2 & 49,9 \\
\hline 95PHB/5MMT-O & 5,2 & 0,126 & & & & 174 & & 76,5 & 55,2 \\
\hline 95PHB/5MMT-E & 5,9 & 0,033 & & & 160 & 169 & & 61,2 & 44,1 \\
\hline 90PHB/10MMT & 5,2 & 0,071 & & & 155 & 167 & & 66,5 & 50,6 \\
\hline 90PHB/10MMT-D & 6,6 & 0,167 & & & 159 & 170 & & 72,7 & 55,3 \\
\hline 90PHB/10MMT-O & 7,2 & 0,065 & & & 168 & 174 & & 72,6 & 55,3 \\
\hline 90PHB/10MMT-E & 6,6 & 0,141 & & & 160 & 168 & & 80,0 & 60,9 \\
\hline
\end{tabular}



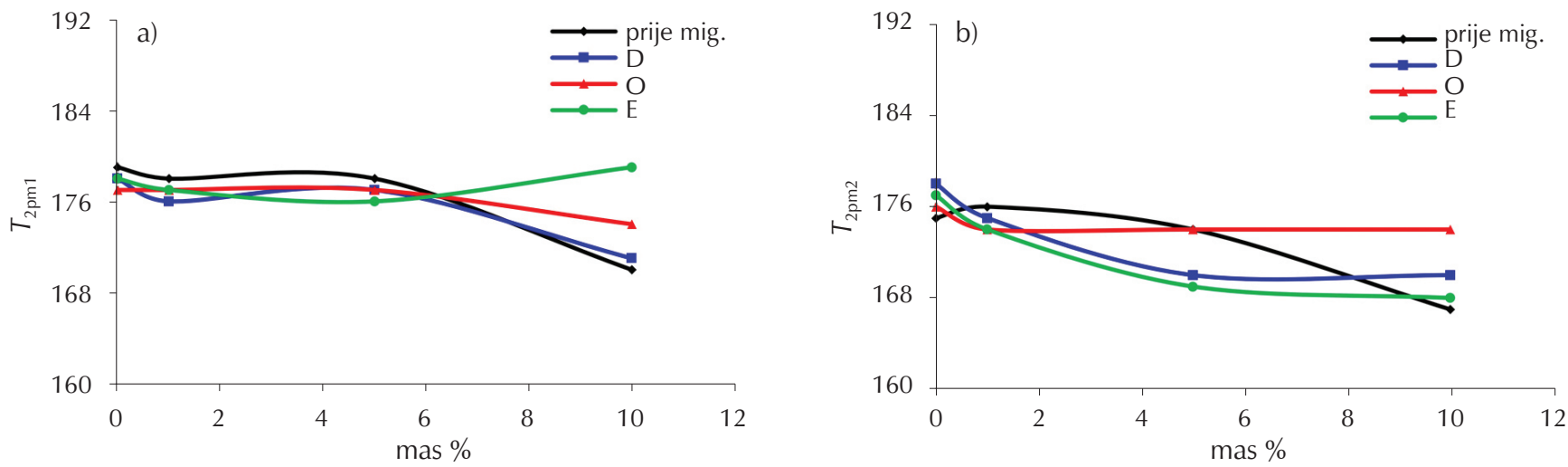

Slika 10 - Ovisnost $T_{2 \mathrm{pm} 1}$ (a) i $T_{2 \mathrm{pm} 2}$ (b) o udjelu punila u kompozitima PHB/MMT prije i nakon ispitivanja migracije u modelnim otopinama

Fig. $10-T_{2 \mathrm{pm} 1}$ (a) and $T_{2 \mathrm{pm} 2}$ (b) as a function of the filler content in PHB/MMT composites before and after migration testing in the food simulants

plinskom prijelazu te se iz dobivenih podataka ne uočava značajna razlika u toplinskom prijelazu prije i nakon ispitivanja migracije u modelnu otopinu kao ni razlika u djelovanju upotrijebljenih modelnih otopina.

Taljenje se javlja kod svih uzoraka, ali se kod nekih uzoraka javlja s dva ili više endotermnih pikova ili ramena, kao što je već spomenuto i prikazano u tablicama 3 i $4\left(T_{1 \mathrm{pm}}, T_{2 \mathrm{pm}} \mathrm{i}\right.$ $\left.T_{3 \mathrm{pm}}\right)$. Prvi pik, tj. $T_{1 \mathrm{pm}}$ se nalazi u rasponu od 155 do $171^{\circ} \mathrm{C}$, $T_{2 p m}$ od 166 do $179{ }^{\circ} \mathrm{C} \mathrm{a} T_{3 p m}$ od 184 do $190{ }^{\circ} \mathrm{C}$. Prema literaturi, u slučaju $T_{2 \mathrm{pm}}$ radi se o taljenu kristalne faze koja se javlja pri temperaturama taljenja bliskim izvornom prahu PHB $\left(T_{\mathrm{pm}}=175^{\circ} \mathrm{C}\right) .{ }^{3}$ Prvi endotermni pik isključivo se javlja kod kompozita s 5 i 10 mas\% MMT-a. Nakon prvog zagrijavanja uočava se samo kod uzoraka PHB/10MMT-O i PHB/10MMT-E, a nakon drugog zagrijavanja kod uzoraka PHB/5MMT, PHB/5MMT-D i PHB/5MMT-E te uzoraka $\mathrm{PHB} / 10 \mathrm{MMT}$ prije $\mathrm{i}$ nakon ispitivanja migracije $\mathrm{u}$ svim modelnim otopinama, tablice $3 \mathrm{i} 4$. Vrijednosti $T_{1 \mathrm{pm}}$ kod uzoraka kod kojih je uočen toplinski prijelaz znatno se razlikuju prije i nakon ispitivanja migracije u modelnim otopinama, a vidi se i razlika u djelovanju upotrijebljenih modelnih otopina. Ipak, broj dobivenih rezultata nije dovoljan da se donese zaključak o tome koja od modelnih otopina ima veći utjecaj na toplinska svojstva istraživanih kompozita. M. Erceg ${ }^{3}$ također je uočio pojavu dodatnog manjeg pika pri nižim temperaturama (za oko $10{ }^{\circ} \mathrm{C} \mathrm{u} \mathrm{od-}$ nosu na veći pik), što je pripisao taljenju kristalne faze niže molekulne mase zbog utjecaja pripreme uzoraka. Pojavljivanje prvog pika taljenja i u ovom radu prema M. Erceg $^{3}$ ukazuje na prisutnost niže molekulne mase PHB-a, čime se potvrdila hidroliza PHB-a uočena UV/Vis spektroskopijom. Drugi endotermni pik, najveći pik taljenja javlja se kod svih uzoraka nakon prvog i drugog zagrijavanja. Po vrijednostima $T_{2 \mathrm{pm} 1}$ i $T_{2 \mathrm{pm} 2}$ svih uzoraka ne uočava se utjecaj modelnih otopina zbog migracije punila iz kompozita i/ili interakcije modelnih otopina s komponentama kompozitima PHB/MMT, tj. promjene su neznatne. Treba napomenuti da zbog pojave više pikova taljenja koji se preklapaju, kod pojedinih uzorka dolazi do utjecaja na vrijednosti $T_{2 \mathrm{pm},}$ ali se ipak općenito može zaključiti da provedeno ispitiva- nje migracija nije promijenilo $T_{2 \mathrm{pm}}$, tablice 3 i 4 te slika 10 . Treći endotermni pik se isključivo javlja samo nakon prvog zagrijavanja. Kod uzorka 100PHB/OMMT ne javlja se prije ispitivanja migracije, dok se uočava nakon ispitivanja migracije u svim modelnim otopinama, a vrijednosti $T_{3 \mathrm{pm} 1} \mathrm{im}$ se malo razlikuju. Kod uzorka 99PHB/1MMT spomenuto taljenje se javlja samo prije ispitivanja migracije, a u slučaju uzorka $95 \mathrm{PHB} / 5 \mathrm{MMT}$ prije i nakon ispitivanja migracije u svim modelnim otopinama te im se vrijednosti $T_{3 \mathrm{pm} 1}$ malo razlikuju. Uzorci 90PHB/10MMT spomenuto taljenje pokazuju samo nakon ispitivanja migracije u destiliranoj vodi i $3 \%$-tnoj otopini octene kiseline, a vrijednosti $T_{3 \mathrm{pm} 1}$ su im gotovo iste. $R$. M. Ramos Wellen i sur. ${ }^{22}$ istraživali su utjecaj brzina zagrijavanja i hlađenja (uvjeti prerade uzoraka) na taljenje i kristalizaciju PHB-a te također uočili pojavu više pikova taljenja koje su pripisali taljenju kristala PHB-a različitih veličina $\mathrm{i}$ toplinske stabilnosti. Prema istraživanju navedenih autora ${ }^{22}$ treći endotermni pik koji se javlja i u ovom radu isključivo je odraz taljenja većih i savršenih kristala PHB-a nastalih pod utjecajem toplinske prošlosti materijala. Potvrda tome je izostanak trećeg endotermnog pika taljenja kod svih uzoraka nakon drugog zagrijavanja a uslijed uklanjanja toplinske prošlosti uzoraka. Područje pojavljivanja prvog pika taljenja u ovom istraživanju poklapa se s područjem pojavljivanja pika taljenja kod M. Erceg, ${ }^{3}$ a područje pojavljivanja trećeg pika taljenja s područjem pojavljivanja pika taljenja $\operatorname{kod} R$. M. Ramos Wellen i sur. ${ }^{22}$ Ako se rezultati taljenja promotre samo s aspekta drugog zagrijavanja, onda se utjecaj modelnih otopina s pomoću DSC-a uočava jedino kod kompozita s 5 i 10 mas\% u vidu pojavljivanja prvog pika taljenja. Dobiveni rezultati dobro se slažu s rezultatima UV/Vis spektroskopije kod koje je uočeno da se s povećanjem udjela MMT-a poveća utjecaj modelnih otopina, tj. hidroliza PHB-a. Uslijed preklapanja više endotermi taljenja $\Delta H_{\mathrm{m} 1}$ i $\Delta H_{\mathrm{m} 2}$ predstavljaju ukupnu entalpiju taljenja nakon prvog i drugog zagrijavanja, a za određivanje entalpije taljenja pojedine kristalne faze potrebno je izvršiti dekonvoluciju pikova taljenja. Iz vrijednosti $\Delta H_{\mathrm{m} 1}$ i $\Delta H_{\mathrm{m} 2}$ zbog preklapanja endotermi taljenja teško je zaključiti na koji način modelne otopine djeluju na vrijednost entalpije taljenja uzoraka $\left(\Delta H_{\mathrm{m} 1}=57-79 \mathrm{Jg}^{-1} \mathrm{i}\right.$ 
$\left.\Delta H_{\mathrm{m} 2}=60-81 \mathrm{Jg}^{-1}\right)$, tablice 3 i 4 . Iz promjene vrijednosti stupnja kristalizacije $\left(X_{\mathrm{c} 1}\right.$ i $\left.X_{\mathrm{c} 2}\right)$ također je teško zaključiti o utjecaju modelnih otopina na kristalizaciju PHB-a kod svih uzoraka, tablice 3 i 4 te slika 11. Moglo bi se općenito zaključiti, imajući na umu uočenu hidrolizu PHB-a, da se vrijednost $X_{\mathrm{c} 1}$ nakon ispitivanja migracije mijenjaju i to u rasponu $2-14 \%$ od vrijednosti $X_{\mathrm{c} 1}$ prije ispitivanja migracije. Najveća promjena uočena je kod uzorka 99PHB/1MMT u 3 \%-tnoj otopini octene kiseline. Nakon uklanjanja toplinske prošlosti materijala vrijednosti $X_{c 2}$ određene nakon ispitivanja migracije mijenjaju se u rasponu $1-14 \%$ od vrijednosti $X_{c 2}$ prije ispitivanja migracije te je najveća promjena uočena kod ispitivanja migracije na uzorku 100PHB/OMMT u 15 \%-tnoj otopini etanola.

Kristalizacija iz taline javlja se kod svih uzoraka, slike 8 i 9. Kod kompozita 100PHB/0MMT i 99PHB/1MMT ne uočava se značajna promjena $T_{\text {pmc }}$ nakon ispitivanja migracije, dok se kod kompozita 95PBH/5MMT i 90PHB/10MMT uočavaju veće promjene, tablica 3 i slika 12. $T_{\text {pmc }}$ je kod uzorka 95PBH/5MMT-D manji za $6{ }^{\circ} \mathrm{C}$, a kod uzorka $95 \mathrm{PBH} / 5 \mathrm{MMT}-\mathrm{O}$ veći za $5{ }^{\circ} \mathrm{C}$ od $T_{\text {pmc }}$ prije ispitivanja migracije. U slučaju uzorka 90PHB/10MMT-O $T_{\text {pmc }}$ je veći za
$6{ }^{\circ} \mathrm{C}$ u odnosu na $T_{\text {pmc }}$ prije ispitivanja migracije. Navedeno se poklapa $s$ uočenim utjecajem modelnih otopina na kompozite s 5 i 10 mas\%. Vrijednosti $\Delta H_{\text {mc }}$ značajno se ne mijenjaju nakon ispitivanja migracije kod svih uzoraka, tj. promjene su u rasponu $1-10 \mathrm{Jg}^{-1}$, tablica 3 i slika 12 .

Staklasti prijelaz javlja se kod svih uzoraka prije i nakon ispitivanja migracije u modelnim otopinama. Kod većine uzoraka staklasti prijelaz javlja se kao slabo izražen široki prijelaz. Zbog otežanog određivanja granica prijelaza vrijednosti $T_{\mathrm{mg}}$ i $\Delta C_{\mathrm{p}}$ prikazane u tablici 4 nisu prihvatljive za analizu.

Iz dobivenih toplinskih značajki DSC krivulja može se zaključiti da modelne otopine mijenjaju toplinska svojstva PHB-a te ujedno samih kompozita zbog razgradnje, tj. hidrolize PHB-a koja se očituje pojavom taljenja kristalne faze niže molekulne mase. Rezultati dobiveni DSC analizom slažu se s rezultatima UV/Vis spektroskopije. Zbog utjecaja razgradnje uzoraka nisu se uočili podatci koji bi ukazali na migraciju punila i nije uočena velika razlika u utjecaju različitih modelnih otopina. Razgradnja kompozita nije poželjna jer se mijenjaju ostala svojstva materijala i time se dovodi u pitanje njihova primjena kao ambalažnog materijala u prehrambenoj industriji.
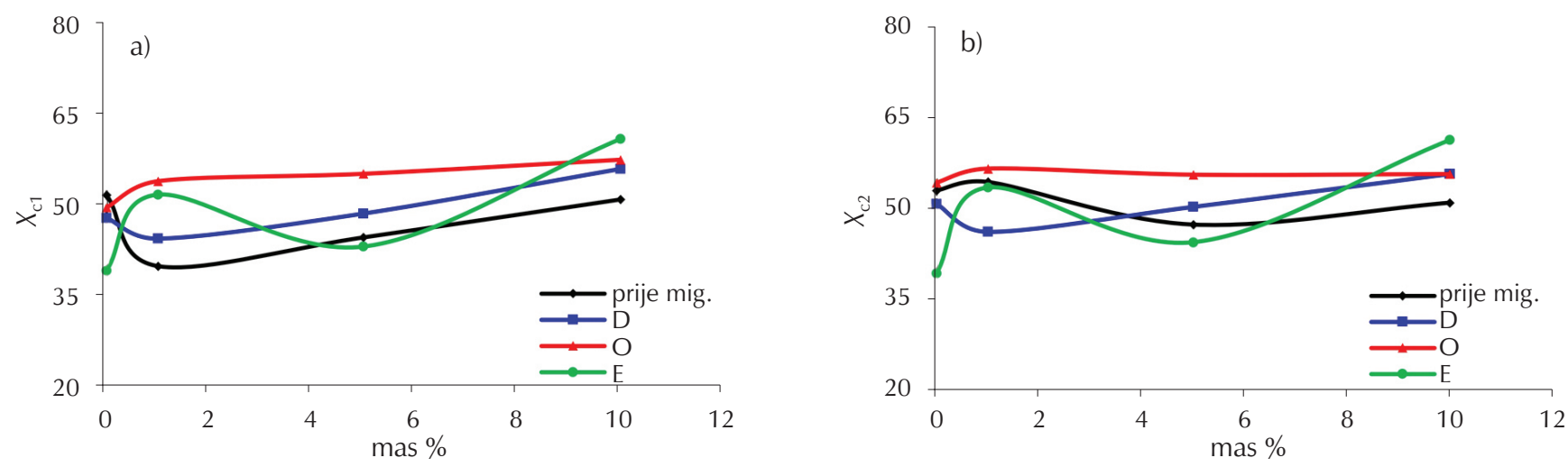

Slika 11 - Ovisnost $X_{\mathrm{c} 1}$ (a) i $X_{\mathrm{c} 2}$ (b) o udjelu punila u kompozitima PHB/MMT prije i nakon ispitivanja migracije u modelnim otopinama Fig. $11-X_{\mathrm{c} 1}$ (a) and $X_{\mathrm{c} 2}$ (b) as a function of the filler content in PHB/MMT composites before and after migration testing in the food simulants
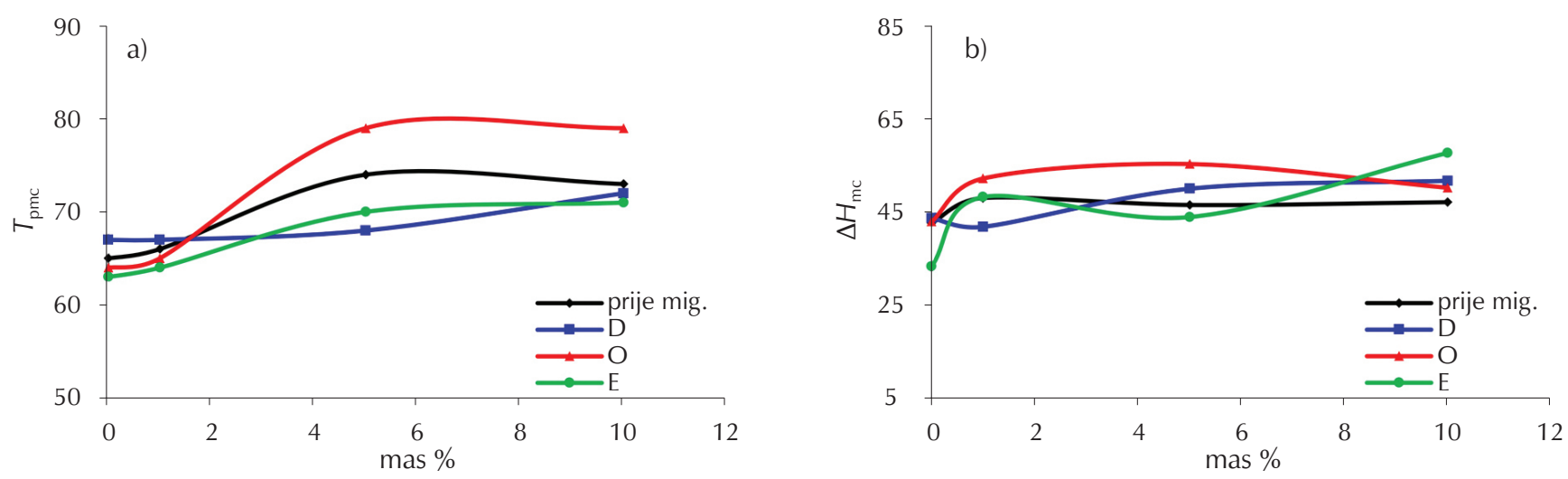

Slika 12 - Ovisnost $T_{\text {pmc }}$ (a) i $\Delta H_{\mathrm{mc}}$ (b) o udjelu punila u kompozitima PHB/MMT prije i nakon ispitivanja migracije u modelnim otopinama

Fig. $12-T_{\text {pmc }}$ (a) and $\Delta H_{\mathrm{mc}}$ (b) as a function of the filler content in PHB/MMT composites before and after migration testing in the food simulants 


\section{Zaključak}

Sve referentne suspenzije MMT-a u modelnim otopinama pokazuju apsorpcijski maksimum oko $242 \mathrm{~nm}$ te povećanje apsorbancije s povećanjem koncentracije MMT-a u modelnim otopinama. Faktori korelacije baždarnih pravaca su iznad 0,96, što ukazuje na primjenjivost jednadžbe 1 u određivanju nepoznate koncentracije MMT-a u modelnim otopinama nakon ispitivanja migracije. UV/Vis spektri modelnih otopina nakon ispitivanja migracije na kompozitima PHB/MMT pokazuju apsorpcijska područja koja ukazuju na prisutnost nehidroliziranog i hidroliziranog PHB-a. Povećanjem udjela MMT-a u kompozitima povećava se utjecaj modelnih otopina. Potvrdio se utjecaj različitih uvjeta na hidrolizu PHB-a. Utvrđivanje migracije MMT-a s UV/Vis spektroskopijom nije bilo moguće zbog hidrolize PHB-a. Pomoću DSC analize uočena je promjena taljenja PHB-a, tj. kod nekih uzoraka kompozita javlja se s dva ili više endotermnih pikova. Pojavljivanje prvog pika taljenja ukazuje na prisutnost PHB-a niže molekulne mase, čime se potvrdila hidroliza PHB-a uočena UV/Vis spektroskopijom. Prvi endotermni pik isključivo se javlja kod kompozita s 5 i 10 mas\% MMT-a. Dobiveni rezultati dobro se slažu s rezultatima UV/Vis spektroskopije kod koje je uočeno da se s povećanjem udjela MMT-a poveća utjecaj modelnih otopina. Ni kod DSC-a se zbog utjecaja razgradnje PHB-a nisu uočili podatci koji bi ukazali na migraciju punila i nije uočena velika razlika u utjecaju različitih modelnih otopina. Razgradnja kompozita nije poželjna jer se mijenjaju ostala svojstva materijala i time se dovodi u pitanje njihova primjena kao ambalažnog materijala u prehrambenoj industriji. Provedenim istraživanjem ukazalo se na potencijal uporabe UV/Vis spektroskopije kod ispitivanja utjecaja modelnih otopina na polimerne kompozite. UV/Vis spektroskopija kao tehnika za određivanje migracije punila iz polimerne ambalaže je neistražena, tj. nema sličnih istraživanja, zbog čega se otvara čitav spektar polimernih kompozita i uvjeta za buduća istraživanja.

\section{Popis kratica i simbola List of abbreviations and symbols}
$\mathrm{PBH}-$ poli(3-hidroksibutirat)
- poly(3-hydroxybutyrate)
MMT - montmorilonit
- montmorillonite
UV/Vis - spektroskopija u ultraljubičastom i vidljivom spektralnom području
- ultraviolet-visible spectroscopy
DSC - diferencijalna pretražna kalorimetrija
- differential scanning calorimetry
PET - poli(etilen-tereftalat)
- poly(ethylene terephthalate)
$\overline{M_{v}} \quad-$ viskozni prosjek relativnih molekulnih masa, $\mathrm{g} \mathrm{mol}^{-1}$
- viscosity average molecular weight, $\mathrm{g} \mathrm{mol}^{-1}$
[ $\eta$ ] - intrinzička viskoznost, $\mathrm{cm}^{3} \mathrm{~g}^{-1}$
- intrinsic viscosity, $\mathrm{cm}^{3} \mathrm{~g}^{-1}$
$\lambda-$ valna duljina, $\mathrm{nm}$
- wavelength, $\mathrm{nm}$

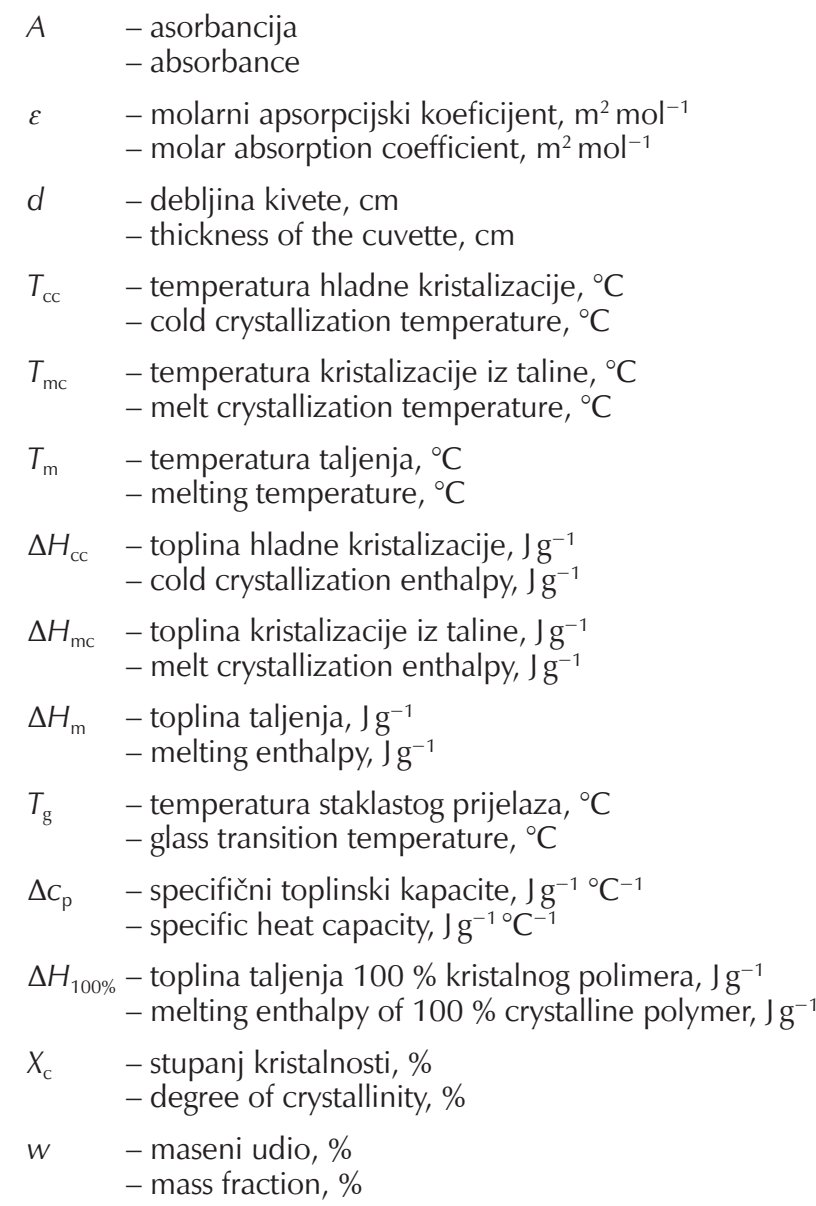

\section{Literatura}

\section{References}

1. N. Stipanelov Vrandečić, Ambalaža, Kemijsko-tehnološki fakultet, Split, 2010, str. 7-11, 30.

2. I. Vujković, K. Galić, M. Vereš, Ambalaža za pakiranje namirnica, D. Milijević (ur.), Tektus, Zagreb, 2007, str. 173-174.

3. M. Erceg, Doktorska disertacija, Kemijsko-tehnološki fakultet, Split, 2007., str. 6, 19, 43, 145-146.

4. S. Pavlidou, C. D. Papaspyrides, A review on polymer-layered silicate nanocomposites, Prog. Polym. Sci. 33 (12) (2008) 1119-1198, doi: https://doi.org/10.1016/j.progpolymsci.2008.07.008.

5. C. Sharma, R. Dhiman, N. Rokana, H. Panwar, Nanotechnology: An Untapped Resource for Food Packaging, Front. Microbiol. 12 (2017) 1-22, doi: https://doi.org/10.3389/ fmicb.2017.01735.

6. V. G. L. Souza, A. L. Fernando, Nanoparticles in food packaging: Biodegradability and potential migration to food - A review, Food Packag. Shelf 8 (2016) 63-70, doi: https://doi. org/10.1016/j.fpsl.2016.04.001.

7. W. Karickhoff, G. W. Bailey, Optical Absorption Spectra of Clay Minerals, Clays Clay Miner. 21 (1) (1973) 59-70, doi: https://doi.org/10.1346/CCMN.1973.0210109.

8. T. Ke, X. Sun, Effects of moisture content and heat treatment on the physical properties of starch and poly(lactic acid) blends, J. Appl. Polym. Sci. 81 (2001) 3069-3082, doi: https://doi.org/10.1002/app.1758.

9. J. Alin, M. Rubino, R. Auras, Effect of the Solvent on the Size of Clay Nanoparticles in Solution as Determined Using an Ultraviolet-Visible (UV-Vis) Spectroscopy Methodology, 
Appl. Spectrosc. 69 (6) (2015) 671-678, doi: https://doi. org/10.1366/14-07704.

10. B. T. Franzin, C. P. Lupi, L. A. Martins, F. C. Guizellini, C. C. Marques dos Santos, I. A. Pastre, F. L. Fertonani, Thermal and electrochemical studies of Fe(III) organophilic montmorillonite, J. Therm. Anal. Calorim. 131 (1) (2018) 713-723, doi: https://doi.org/10.1007/s10973-017-6327-z.

11. A. Getachew, F. Woldesenbet, Production of biodegradable plastic by polyhydroxybutyrate (PHB) accumulating bacteria using low cost agricultural waste material, BMC Res. Notes 9 (2016) 1-9, doi: https://doi.org/10.1186/s13104-0162321-y.

12. M. Kaleeswari, P. Selvi, Production of bioplastic from the isolated Lactobacillus, European J. Biomed. Pharm. Sci. 5 (2018) 604-608.

13. P. Polyáka, E. Dohovitsa, G. N. Nagyc, B. G. Vértessy, G. Vörös, B. Pukánszky, Enzymatic degradation of poly-[(R)-3-hydroxybutyrate]: Mechanism, kinetics, consequences, Int. J. Biol. Macromol. 112 (2018) 156-162, doi: https://doi. org/10.1016/j.ijbiomac.2018.01.104

14. H. Li, S. Zhou, T. Johnson, K. Vercruysse, O. Lizhi, P. Ranganathan, N. Phambu, A. J. Ropelewski, T. W. Thannhauser, Genome Structure of Bacillus cereus tsu1 and Genes Involved in Cellulose Degradation and Poly-3-Hydroxybutyrate Synthesis, Int. J. Polym. Sci. 2017 (2017) 1-12, doi: https://doi. org/10.1155/2017/6192924

15. J. Yu, D. Plackett, L. X. L. Chen, Kinetics and mechanism of the monomeric products from abiotic hydrolysis of poly[(R)-3-hydroxybutyrate] under acidic and alkaline conditions, Polym. Degrad. Stab. 89 (2005) 289-299, doi: https:// doi.org/10.1016/j.polymdegradstab.2004.12.026.

16. K. Mukai, K. Yamada, Y. Doi, Kinetics and mechanism of het- erogeneous hydrolysis of poly[(R)-3-hydroxybutyrate] film by PHA depolymerases, Int. J. Biol. Macromol. 15 (1993), 361366, doi: https://doi.org/10.1016/0141-8130(93)90054-P.

17. P. Lathwal, K. Nehra, M. Singh, P. Jamdagni, J. S. Rana, Optimization, Optimization of Culture Parameters for Maximum Polyhydroxybutyrate Production by Selected Bacterial Strains Isolated from Rhizospheric Soils, Pol. J. Microbiol. 64 (2015), 227-239, doi: https://doi.org/10.5604/01.3001.0009.2118.

18. R. Bhati, S. Samantaray, L. Sharma, N. Mallick, Poly- $\beta$-hydroxybutyrate accumulation in cyanobacteria under photoautotrophy, Biotechnol. J. 5 (2010), 1181-1185, doi: https:// doi.org/10.1002/biot.201000252.

19. Y. S. Mostafa, S. A. Alrumman, K. A. Otaif, S. A. Alamri, M. S. Mostafa, T. Sahlabji, Production and Characterization of Bioplastic by Polyhydroxybutyrate Accumulating Erythrobacter aquimaris Isolated from Mangrove Rhizosphere, Molecules 25 (2020), 1-20, doi: https://doi.org/10.3390/molecules25010179.

20. M. Scandola, M. L. Focarete, G. Frisoni, Simple Kinetic Model for the Heterogeneous Enzymatic Hydrolysis of Natural Poly(3-hydroxybutyrate), Macromolecules 31 (1998), 38463851, doi: https://doi.org/10.1021/ma980137y.

21. A. Cao, Y. Arai, N. Yoshie, K.-I. Kasuya, Y. Doi, Y. Inoue, Solid structure and biodegradation of the compositionally fractionated poly(3-hydroxybutyric acid-co-3-hydroxypropionic acid)s, Polymer 40 (1999), 6821-6830, doi: https://doi. org/10.1016/S0032-3861(99)00044-0.

22. R. M. Ramos Wellen, M. Silveira Rabello, I. C. Araujo Júnior, G. J. Macedo Fechine, E. L. Canedo, Melting and crystallization of poly(3-hydroxybutyrate): effect of heating/cooling rates on phase transformation, Polímeros 25 (3) (2015) 296304, doi: https://doi.org/10.1590/0104-1428.1961.

\section{SUMMARY \\ The Influence of Food Simulants on Poly(3-hydroxybutyrate)/Montmorillonite Composites Sanja Perinović Jozić, Ana Mihovilović, and Branka Andričić}

The aim of this work was to prepare poly(3-hydroxybutyrate)/montmorillonite (PHB/MMT) composites on the laboratory press with heating, and to determine the influence of different food simulants on the composites and the filler migration. Analysis of the food simulants after migration testing was conducted with UV/Vis spectroscopy. Due to the established hydrolysis of PHB under the influence of the food simulants, it was impossible to determine the migration of MMT from PHB/MMT composites. Differential scanning calorimetry (DSC) confirmed the degradation of PHB. This research showed the potential of UV/Vis spectroscopy in dealing with the influence of food simulants on polymer composites.

\section{Keywords}

Poly(3-hydroxybutyrate), montmorillonite, food simulants, migration, UV-Vis spectroscopy, thermal properties

Faculty of Chemistry and Technology

University of Split

Ruđera Boškovića 35

21000 Split, Croatia
Original scientific paper Received December 20, 2019 Accepted May 4, 2020 